\title{
Dijital Oyunlarda Avatar-Kimlik İlişkisi: Üniversite Öğrencileri Üzerine Bir Araştırma ${ }^{1}$
}

\author{
Tahsin Eren SAYAR ${ }^{2}$ ve Seçkin ÖZMEN ${ }^{3}$
}

Öz

Yaşamın her alanında kendisine yer bulan oyun oynama eylemi gelişen internet teknolojileriyle birlikte dijital bir forma kavuşmuştur. 1960’lı yıllardan itibaren kültürden ekonomiye kadar çok sayıdaki yaşam pratiğinde köklü değişikliklere neden olan dijitalleşme sürecinin oyun oynama eylemi üzerindeki etkisi, bugün halen tartışlagelen ve akademik ilgiye mazhar olan bir disiplin olarak öne çıkmaktadır. Özellikle günümüzde Steam ve Play Station Store gibi popüler platformlar aracillğıyla performans sergileyen dijital oyuncuların/kullanıcıların oluşturdukları sanal kimlikler, yani avatarlar ise sundukları yeniden üretilen kimlik modeli ile dijital oyunları psikoloji bilimi ile yakın temasa sahip interdisipliner bir alan haline getirmiştir. Bu bağlamda dijitalleşme süreci çatısı altında oyun ve kimlik tartışmalarını çoklu eksende yürüten bu çalışmanın sorusu "Dijital oyunlarda belirlenen avatarlar kişilerin gerçek yaşamdaki kimlikleri ile nasıl bir ilişkiye sahiptir?” olarak belirlenmiştir. Çalışmanın amacı ise kullanıcıların seçtikleri avatarların kişilerin kimlik ve benlik yapısı üzerinde ne tür etkiler oluşturduğunu ortaya çıkarmaktır. Odak Grup Görüşmesi yönteminin kullanıldı̆̆ı çalışmada örneklem olarak Yalova Üniversitesi Sanat ve Tasarım Fakültesi İletişim Sanatları 3. sınıf öğrencileri ve Yalova Üniversitesi Mühendislik Fakültesi Bilgisayar Mühendisliği 4. sınıf öğrencilerinden toplamda 12 kişi seçilmiştir. Yapılan araştırma neticesinde avatarların kişilerin kimlik yapılarında sanal kimliğe sahip olma arzusu, anonimlik, çoklu kimlik, liderlik ve aidiyet duygusunu geliştirme gibi etkiler oluşturduğu sonucuna ulaşılmışıtır.

Anabtar Kelimeler: Dijital Oyun, Dijital Kimlik, Benlik, Avatar

\section{Avatar-Identity Relationship in Digital Games: A Study on University Students}

\begin{abstract}
The act of playing games, which finds its place in all areas of life, has gained a digital form with the developing internet technologies. The effect of the digitalization process, which has caused radical changes in many life practices, from culture to economy since the $1960 \mathrm{~s}$, on the act of playing, stands out as a discipline that is still debated and attracts academic attention today. Virtual identities, namely avatars, created by digital players/users performing through popular platforms such as Steam and Play Station Store today, have made digital games an interdisciplinary field with close contact with the science of psychology, with the reproduced identity model they offer. In this context, the question of this study, which carries out the game and identity discussions on multiple axis under the umbrella of the digitalization process, is "What kind of relationship do the avatars determined in digital games have with the identities of people in real life?" has been determined. The aim of the study is to reveal what kind of effects the avatars chosen by the users have on the identity and self-structure of the people. In the study in which the Focus Group Interview method was used, a total of 12 students from Yalova University Art and Design Faculty Communication Arts 3rd year students and Yalova University Engineering Faculty Computer Engineering 4th year students were selected as a sample. As a result of the research, it was concluded that avatars create effects such as the desire to have a virtual identity, anonymity, multiple identity, leadership and sense of belonging in the identity structures of people.
\end{abstract}

Key Words: Digital Game, Digital Identity, Ego, Avatar

\section{Atıf İçin / Please Cite As:}

Sayar, E. T. ve Özmen, S. (2022). Dijital oyunlarda avatar-kimlik ilişkisi: üniversite öğrencileri üzerine bir araştırma. Manas Sosyal Araştırmalar Dergisi, 11(1), 320-341.

Geliş Tarihi / Received Date: 25.06.2021

Kabul Tarihi / Accepted Date: 2.09.2021

\footnotetext{
${ }^{1}$ Bu makale, danışmanlığını Prof. Dr. Seçkin Özmen'in yaptığı, Dr. Tahsin Eren Sayar tarafindan hazırlanan İstanbul Üniversitesi Sosyal Bilimler Enstitüsü Radyo Televizyon Sinema Anabilim Dalı, "Dijital Oyunlar Üzerinden Profilleşen Kimlikler" başlıklı doktora tez çalışmasından üretilmiştir. Bu çalışma İstanbul Üniversitesi Bilimsel Araştırma Projeleri Koordinasyon Birimi tarafından desteklenmiştir. Proje numarası: 37648

2 Dr. - İstanbul Üniversitesi, Sosyal Bilimler Enstitüsü, sayartahsineren@gmail.com

(iD) ORCID: 0000-0002-6057-2989

${ }^{3}$ Prof. Dr. - İstanbul Üniversitesi, İletişim Fakültesi, Radyo, Televizyon ve Sinema Bölümü, seckinozmen@gmail.com

(iD) ORCID: 0000-0002-4871-4921
} 


\section{Giriş}

Yaşamın varlığı kadar eski olan oyun oynama eylemi, yalnızca insanlar için değil, aynı zamanda hayvanlar için de içgüdüsel bir eylemdir. Bireysel olduğu gibi topluluk halinde de icra edilebilen oyun, canlı varlıkların hayatta kalma güdülerine hizmet eden, eğlence ve sosyal amaçlı fiziki ve ruhsal eylemler olarak tanımlanmaktadır. Söz gelimi, hayvanlarda yaşamın sürekliliği için gereken avlanma davranışı olarak kodlanan oyun, ilk insanlarda ise kültürel öğeleri toplum yaşantısına yerleştirme ve dini ayinler şeklinde kurgulanmış ve uygulanmıştır. Zaman içerisindeki uygulamalarının yanı sıra oyunun bilime konu oluşu Antik Çağ’da Aristo ve Platon ile başlamışır. Modern dönemlerde ise Hollandalı filozof Johan Huizinga ve Fransız entelektüel Roger Caillois başta olmak üzere pek çok düşünürün eserleri ile kuramsallaşan oyun kavramı, bugün gelişen teknolojinin rüzgârını arkasına alarak küreselleşme sürecine girmiş ve dijitalleşme evrimini büyük ölçüde tamamlamıştır.

Dijital oyunlar, çevrim içi veya çevrim dışı seçenekleri ile bireysel ve yapay zekâya karşı ya da çoklu ve birbirlerine karşı oynanabilmektedir. Bu yönüyle klasik oyun tanımının sınırlarını aşarak insan-makine etkileşiminin bir çıktısı olan dijital oyunlar, kârlı bir endüstriye dönüşmüş ve ticari bir olgu olarak da yer etmeye başlamıştır. Küresel ölçekte en hızlı büyüyen sektörlerden biri olan dijital oyun sektörü, büyüme hızında otomotiv ve enerji gibi temel sektörleri ve eğlence alanının amiral gemisi kabul edilen sinema sektörünü geride bırakmıştır (Güvenli İnternet Merkezi, 2019, s. 8). Kişisel bilgisayar, oyun konsolu ve mobil cihazlar üzerinden icra edilen dijital oyunların, 2018 yllında yaklaşık 138 milyar dolar seviyesinde olan pazar büyüklüğ̈nün, 2021 yllında ise 180 milyar dolara yaklaşacağı tahmin edilmektedir (Newzoo, 2018). Söz konusu pazar büyüklüğü arz-talep dengesi kapsamında değerlendirildiğinde dünya genelinde dijital oyun oynayanların istatistiki verilerine ilişkin çıarımlar yapılabilmektedir. Dünyada bir milyarın üzerinde insan, dijital oyun oynarken (Bilgi Teknolojileri Kurumu, 2018) ülkemizde 2019 itibariyle 30 milyon insanın dijital oyun oynadığı saptanmıştır (Güvenli İnternet Merkezi, 2019, s. 10). Bu yönüyle çeşitli alanlardan gelen araştırmacıların çalıșmalarında yer bulan dijital oyun kavramı, akademik ilginin de odağı olmuştur. Özellikle kamuoyu araştırmalarından elde edilen veriler 1şığında 16-24 ile 25-34 yaş aralığındaki erkek bireylerin dijital oyunları yoğun olarak kullanması, kişisel özellikler üzerinde düşünme gerekliliğini doğurmuştur. Bu kişisel özelliklerin en dikkat çekenlerinden biri kullanıcıların dijital oyunlarda yarattıkları avatarlar ile sergiledikleri tutum ve davranışların altyapısında yatan nedenler olarak görülmektedir. Söz gelimi, kullanıcıların gerçek yaşamdaki eğilim ve özelliklerinin, dijital oyun oynama tercihlerine olan etkisinden bu oyunlarda sergiledikleri profillerin tutum ve davranışlarına, hatta bu tutum ve davranışların gerçek yaşamdaki kimlikleri ne ölçüde yansıttığına kadar uzanan ve geniş bir yelpazede cevaplanması gereken bir dizi olgu bulunmaktadır.

Günümüzde Steam ve Play Station Store gibi birçok dijital oyun platformu aracıllğgyla dijital oyunlarda oluşturulan avatarlar için satın almalar yapılmaktadır. Bu satın almaların, avatarlara görsel katkı sağlayan unsurlar sunmasına karşın, başka hiçbir avantaj sağlamaması oyuncuların bu mecralarda niçin satın alma gerçekleştirdikleri sorusunu gündeme getirmektedir. Bu açıdan bakıldığında dijital oyunlarda belirlenen avatarların kişilerin gerçek yaşamlarındaki kimlik yapıları ile ne tür bir ilişki içerisinde olduğu üzerinde durulması gereken bir husus olarak dikkat çekmektedir. Bu problemden yola çıkarak çalışmanın amacı kullanıcıların seçtikleri avatarların kişilerin kimlik ve benlik yapısı üzerinde ne tür etkiler oluşturduğunu ortaya çıkarmak olarak belirlenmiştir.

Çalışmada Odak Grup Görüşmesi yöntemi kullanılmıştır. Örneklem olarak Yalova Üniversitesi Sanat ve Tasarım Fakültesi İletişim Sanatları Bölümü 3. sınıf ve Yalova Üniversitesi Mühendislik Fakültesi Bilgisayar Mühendisliği Bölümü 4. sınıf öğrencileri seçilmiştir. Her iki bölümden de altı öğrenci belirlenmiş ve görüşmeler altmış dakika olarak gerçekleştirilmiştir. İletişim Sanatları Bölümü yeni medya ve iletişim; Bilgisayar Mühendisliği Bölümü ise internet teknolojileri, sayısallaşma ve dijital oyun tasarımına yönelik ders içeriklerine sahip olduğu için seçilmiştir. Görüşmeler COVID-19 salgını nedeniyle dijital ortamda yapılmış ve toplanan veriler betimsel analiz ile çözümlenmiştir.

\section{Gelenekselden Dijitale Oyunlar ve Özellikleri}

\section{Oyunun Tanımı ve Tarihçesi}

Oyunun bilimselleşme süreci her ne kadar son yüzyılda şekillenmiş olsa da tanımlamalar çok daha eski dönemlere dayanmaktadır. Türk Dil Kurumu'na göre (2020) oyun, yetenek ve zekâ geliştirici, belli kuralları olan, iyi vakit geçirmeye yarayan eğlence olarak tanımlanmaktadır. Metin And ise Oyun ve Bügü adlı 
eserinde oyun sözcüğünün dilimizde birçok farklı anlama işaret ettiğini belirtmektedir. And'a göre (2019, s. 36) Türkçe’de oyun ve oynamak sözcüğünün pek çok anlamı vardır: Çocukların oyunu, dans, dramatik gösterim, kâğıt, zar gibi baht oyunları, sporla ilgili eylemler, hep oyun sözcüğüyle belirtilmektedir.

Araplara Türkçe'yi öğretmek için yazılmış ve uzun yıllar boyunca referans bir kaynak olarak kullanılan Dîvânu Lugâti't-Türk'te de oyunlara ilişkin önemli saptamalar ve kategorileştirmeler yer almaktadır. Burada oyunlar "büyüklerin oynadıkları oyunlar" ve "çocuk oyunları" olarak iki başlık altında incelenmiştir (Türktaş, 1999: 62). Başlık altındaki oyunlara bakıldığında ise genel olarak top, aşık, boynuz, tepük, ötüş ve iplemektir gibi çeşitler çıkmaktadır (Çiçekli, 1970).

İngilizce'de ise durum biraz daha farklıdır çünkü oyun sözcüğ̈̈ "play” ve "game” kelimelerine karşılık gelmektedir. Oyun; İngilizce'de play ve game gibi hem ismi hem de fili karşılamaktadır. Play, oynama filini karşılarken, game ise oyun ismini ifade etmektedir (Yengin, 2012, s. 83). İngilizcenin play ve to play’i semantik açıdan özellikle dikkat çekicidir. Esas olarak oyun, oynamak ve ikincil olarak da, hızlı hareket, jest, el sıkışması, alkışlama, bir müzik aleti çalmak gibi bütün somut hareketleri ifade eden ve Anglosaksonca bir kelime olan plega ve plegan'dan türemiştir (Huizinga, 2015, s. 62). Kendirli’ye göre (2019, s. 51) ise game anlamındaki oyun temel olarak "bir veya daha fazla oyuncu için hazırlanan, oyuncuların bir hedefe ulaşmak için rekabet ettiği, bazı kurallar ve kısıtlamalar içeren bir aktivitedir. Barmanbek, Fidaner ve Merlin'in Kazanı (2009, s. 361) ise oyunu (game) belirli kurallar dâhilinde, genellikle eğlenmek ve psikolojik tatmin amacıyla yapılan eylem topluluğu olarak tanımlamaktadır.

Oyuna ilişkin sistemli ve kategorileştirilmiş en önemli çalışmaları yapan isimlerin başında Hollandalı filozof ve tarih profesörü Johan Huizinga gelmektedir. Homo Ludens adlı çalısmasında oyun oynayan insan tasviri yapan Huizinga, aynı zamanda oyunun kültürel işlevi üzerine önemli saptamalarda bulunmuştur. Oyunun kültürden daha eski bir formda olduğunu dile getiren Huizinga bu durumu, "Kültür kavramını ne kadar daraltsak da, bu kavram her halükârda bir insan toplumunun varlığını gerektirir ve hayvanlar kendilerine oyun oynamalarını öğretmesi için insanın gelmesini beklememişlerdir” şeklinde açıklamaktadır (Huizinga, 2015, s. 16). Huizinga'nın burada oyunun kültürden daha eski olduğunu anlatmasının en önemli sebeplerinden biri insandan önceki dönemde dahi oyunun var olmasıdır. Zira Huizinga, hayvanların çeşitli ritüelleri yerine getirmek için sık sık oyunlara başvurduklarını ifade etmektedir. Bu nedenle Huizinga (2015) hem insan hem de hayvanları kapsayan bir yapıda olduğunu belirttiği oyunun sadece insan âlemiyle sınırlandırılamayacağını ifade etmektedir. Huizinga oyunun aynı zamanda ciddi faaliyetlere yönelik hazırlık safhası içeren bir yapıda olduğunu belirtmektedir. Nitekim taklit ve gevşeme ihtiyacının olduğu noktada insanlar karşılarına çıkacak engellere yönelik oyunları kullanarak bir nevi hazırlık yapmaktadır. Bu durum sonucunda oyunun kültürel süreç ile olan ilisskisi daha da kuvvetlenmektedir. Birçok ilkel topluluk kendine dünyanın esenliğini güvenceye alma olanağ1 sağlayan kutsal ayinlerini, adaklarını, bağışlarını ve törenlerini, kelimenin gerçek anlamıyla, basit oyunlar biçiminde gerçekleştirmektedir (Huizinga, 2015, s. 20-21).

And'a göre (2009, s. 28) oyun, gerçek yaşamdan geçici olarak çıkışı ve oyunun dünyasına girişi temsil etmektedir. Buna karşın Berne ise içine girilen bu sanal dünyanın zamanla bireyin gerçeği olabileceğini belirtmektedir. Berne (2011, s. 19-20) her ne kadar oyunları bir dizi hareket ve hile olarak tanımlasa da aynı zamanda örneğin futbol gibi oyunların insanlar tarafindan aşırı ciddiye alındığını ve bireylerin bu duruma çokça önem atfettiklerini belirtmektedir. Özdoğan'a göre (2005, s. 44) ise oyun kendi içinde birtakım zamansal sınırlara sahiptir. $O$, hayatın içindeki belirli bir zamanda başlamakta ve başka bir zamanda bitmektedir. Aristo da benzer bir şekilde oyunun sağaltıcı yanları olduğunu kabul etmektedir. Ama oyunun özgür insan için yaşamın ereği olamayacağını da savunmaktadır (Oskay, 2001, s. 12).

Kapitalizm sonrası dönemde birçok alanda yaşanan değişimler, oyun kavramının da evrilmesine yol açmıştır. Bu duruma eleştirel bir bakış açısı sunan Ünsal Oskay, gönüllü olarak katılınan oyun formunun zamanla ortadan kalktığını ve önceden sağlanmış bir düzen ve kalıp içerisinde sunulan bir forma geçildiğini belirtmiştir. Bunun sonucunda çağdaş insanın oyunu gerçek bir oyun olma özelliğini yitirmiştir ve eğlence endüstrisi, tatil ve bayram gibi dönemlerde yapılan aktiviteler oyun olarak adlandırılmaya başlanmıştır (Oskay, 2001, s. 18-19).

Sonuç olarak oyun sözcüğünün hem etimolojik hem de felsefi açıdan oldukça fazla tanım ve anlamı olduğu görülmektedir. Fiziksel anlamda bakıldığında oyun, insanların rahatlama gayesine hizmet ederken, psikolojik açıdan irdelendiğinde, gündelik rutinlerin verdiği yorgunluktan kaçışlarına yardımcı olan bir kavram olarak dikkat çekmektedir. Felsefi açıdan bakıldığında ise bir yandan boş zaman kavramına hizmet 
eden bir yapıda karşımıza çıkarken, kapitalizm sonrası dönemde ise özellikle kültür endüstrisinin sunduğu bir olanak olarak göze çarpmaktadır.

\section{Dijitalleşen Oyun}

Soğuk Savaş dönemi sonrası her iki kutbun da teknoloji hamlelerine ağırlık vermesi ve internetin hızlı bir şekilde gelişmesi farklı iletişim alanlarının doğmasına neden olmuştur. İnternet ve uydu teknolojilerinin gelişmesi yeni medyayı ortaya çıkarırken bu dönemde dijital oyun kavramı da hayatımıza girmiştir. Kavramsal olarak oyun tanımına baktı̆̆ımızda karşımıza uzun bir tarihsel süreç çıkmasına karşın dijital oyunlar bu gelişim süreci içerisinde yaklaşı 60 yll gibi bir süreçte hızla gelişerek literatürde yer almaya başlamıştır.

Dijital oyunlar günümüzde birçok farklı disiplin ile iç içe geçmiş bir yapidadır. Yengin’e göre (2012, s. 111) dijital oyunlar yeni iletişim ortamının dijitallik, etkileşimlilik, sanallık, değişkenlik, modülerlik özelliklerini barındıran ve bu özellikleri oyun oynama edimine dâhil eden bireysel iletişim ortamıdır. Sezen'e göre (2011, s. 145) ise dijital oyunlar pek çok açıdan ele alınabilecek teknolojik, kültürel ve ekonomik yapıtlardır. Dijital oyunların bu denli farklı disiplinlerden faydalanan bir yapıda olması 60 yıllık serüveninde onu göz ardı edilemeyecek bir konuma getirmiştir. Siyasetten eğitime, ticaretten kültüre kadar birçok farklı alanda kendisine yer bulan dijital oyunlar, dijitalleşme sürecinin hızlanmasıyla birlikte daha fazla önem verilen bir alan haline gelmiştir.

Dijital oyunların tarihsel serüvenine daha derinlemesine bir bakış atmadan önce geleneksel oyunlar ile olan farklarını incelemekte fayda vardır. Zira dijital oyunların ortaya çıkardığı farklılıklar aslında yeni medya teknolojilerinin sunduğu günümüz olanaklarnna referans vermektedir. Dijital oyunları geleneksel oyunlardan ayıran en önemli farkların başında şüphesiz ki sanallık özelliği gelmektedir. Başka bir deyişle dijital oyunlar bizlere bir sanallık yaratır ve geleneksel oyunlarda her zaman belirgin olan bir mekân ve nesneler vardır. Bireyler bu mekân ve nesneler aracilığıyla oyunu icra ederken bu platformlarda gerçek yaşamın sunamayacağı bir simülasyon durumu söz konusudur.

Dijital oyunları geleneksel oyunlardan ayıran bir diğer önemli husus Binark ve BayraktutatanSütcü’nün $(2008$, s. 49) üzerinde durduğu profesyonel yapilanmadır. Nitekim dijital oyunlar üretim sürecinin bir aracı olduğu için endüstriyel ve maddi bir değer taşır. Oysa geleneksel oyunlarda bu tür bir kazanımdan söz edilmesi mümkün değildir.

Dijital oyunlar ile geleneksel oyunların farkına değindikten sonra dijital oyunların tarihsel serüven içerisindeki değişim yolculuğuna bakıldığında Sezen ve Sezen'in (2011, s. 249) şu tanımlamasını aktarmakta fayda vardır:

\section{“60'l ve 70'li yullarda dijital oyunlar coğunlukla insan-bilgisayar interaksiyonu ve yapay zekâ araștırmalarinda yararlamlan bilimsel deneylerdi. Bu deneyleri yapanlar ve onlarn takipcileri 80'li yullarda onlar teknolojik ve kültürel amalgamlara dönüstürdüler. 90'll ynllarda dijital oyunlar sektörleşme ile ticari olgunluğa kavustular. 2000'li yullarda ise arthe ticaret, kültür, eğitim ve hatta politika gibi alanlarda dikekate değer bir olguya dönüsmüsslerdi."}

Dikkate değer bir olguya dönüşen dijital oyunlar, 2000'li yıllardan itibaren hızla akademik alanın ilgi odağı olmaya başlamıştır. 2001 yılında oyun çalşmaları üzerine çeşitli uluslararası konferanslar düzenlenmiştir ve sahadaki ilk hakemli çevrim içi dergi olan Game Studies yayınlanmıştır. 2002 ve 2003 'te ise, konferansların ve atölyelerin sayısı istikrarlı bir șekilde artmaya devam etmiștir. Dijital metin çalışmalarının bir alt kümesi olarak erken bir başlangıçtan sonra, video oyunu çalışmaları kendi akademik alanını bulmuştur (Frasca, 2003, s. 221).

Dijital oyunlara ilişkin literatür bilgilerinden sonra tarihsel gelişimine yönelik daha somut bilgileri vermek doğru olacaktır. Bilgi Teknolojileri ve İletişim Kurumu bünyesinde 2017 yllında kurulan ve amacını "çocuk ve gençleri internetin olumsuz etkilerinden korumak" olarak belirleyen Güvenli İnternet Merkezi’nin 2019 yılında yayınladığı Dijital Oyunlar Raporu'na göre (2019, s. 6) dijital oyun endüstrisinin temel gelişimleri üç ana kısma ayrılmaktadır. Bunlar mikro işlemcilere geçiş, oyun konsollarının salonlardan evlere taşınması ve bilgisayar tabanlı oyunların geliştirilmesidir. İlk aşama dijital oyunların temel dinamiği olarak görülürken ikinci aşama ile birlikte oyun konsolları eve girerek insanların hayatlarında yer edinmeye başlamıştır. Nihayet son aşamada ise özellikle 2000'li yılların başlarından sonra gelişen bilgisayar oyunları sektörü artık hem bir ticari obje hem de üzerine düşünülerek yanlışlarına yönelik çözüm önerilerinin oluşturulması gereken bir alan haline getirmiştir. 
Dijital oyunların üretim sürecine bakıldığında bilinen en eski interaktif oyun olarak karşımıza Thomas T. Goldsmith Jr, ve Estle Ray Mann tarafından üretilen katot 1şın tüpü (cathode ray tube) çıkmaktadır. Bu oyunun patenti 25 Ocak 1947'de alınmıştır ve oyun 14 Aralık 1948'de yayımlanmıştır (Tezel, 2016, s. 11). Literatürde ilk etkileşimli oyun olarak ise 1962 yllında Steve Russell ve arkadaşlarının Massachusetts Institute of Technology'de yapmiş oldukları Spacewar kabul edilmektedir (Akbulut, 2009, s. 45). Daha sonraki dönemlerde ise Atari oyunları popüler hale gelmiştir ve 70’li yıllardan 90’ların sonuna kadar etkisini sürdürmüştür. Dijital oyunlar asıl önemli atılımını ise 90'lı yılların sonunda PC oyunları ve gelişimini hızlandıran Play Station ve Xbox gibi oyun konsolları sayesinde gerçekleştirmiştir. Bu dönemde üretilen çok sayıda oyun dijital oyun sektörünün hızla büyümesine ve gelişmesine olanak sağlamıştır. Tüm dünyada hızla gelişen dijital oyun sektörü Türkiye'de de kısa bir süre içerisinde popüler hale gelmiştir. Ülkemizde "Pusu" adlı oyun, Hakan Yüksel ve Cem Uzunlar tarafindan geliştirilerek 2005 y1lında satışa sunulmuştur. 2007'de ise PC oyunu olan Kabus 22 geliştirilerek Vestel tarafindan satışa sunulmuştur. (Binark, 2009, s. 135-136).

Dijital oyunlar yıllar içerisinde yaşadığı gelişimlerle birlikte birtakım sınıflandırmalara ayrılmıştır. İlk dönemlerde daha çok eğlence unsurları üzerinden aktarılan dijital oyunlar zamanla birçok farklı sektörün içerisine girmiştir ve ciddi oyunlar kategorisi altında da değerlendirilmeye tabi tutulmuştur. Eğlence unsuru altında değerlendirilen oyunlar birtakım alt sınıflardan oluşmaktadır. Kukul'a göre (2013, s. 25-26) dijital oyunlar; oyunun amacına göre, oynanma şekline göre, oynayan kişi sayısına göre ve oynandığı ortama göre değişmektedir. Kullanılan teknoloji göz önüne alındığında ise dijital oyunlar; konsol oyunları, bilgisayar oyunları ve çevrim içi (online) oyunlar olarak sınıflandırılmaktadır. Bu sınıflandırma daha çok dijital oyunların fiziki yapısı üzerinden yapılmaktadır. Nitekim tarihsel gelişim sürecine bakıldığında önce konsol oyunları sonrasinda bilgisayar oyunları alanı domine eden ve dijital oyunların yayılım sahasını belirleyen önemli fiziki cihazlar olarak karşımıza çıkmıştır.

Eğlence unsuru olarak değerlendirilen dijital oyunlara ilişkin bir diğer sınıflandırma Ögel'e aittir. Ögel'e göre (2014, s. 51-53) dijital oyunlar 10 unsurdan oluşmaktadır. Bunlar, Aksiyon Oyunları, Macera Oyunları, Dövüş Oyunlan1, Bilmece Oyunları, Eğlence Türü Oyunlar, Rol-Oynama (RPG) Oyunlan1, Simülasyon Oyunları, Spor Oyunları, Strateji Oyunları ve Görev İçerikli Aktivitesi Yüksek Oyunlar'dır. Bozkurt ise (2014, s. 6) bu oyunları 5 ana unsur etrafinda şekillendirmiştir. Bunlar; Aksiyon, Macera, Rol Yapma Oyunları, Simülasyon ve Stratejidir. Bu sınıflandırmaların her biri aslında üretilen dijital oyunların içeriklerine göre yapılan sınıflandırmalardır. Zira her oyun yapısı gereği birtakım hikâye ve içerik barındırmaktadır ve bu özellikler o oyunun hangi türe daha yakın olduğuna ilişkin fikir vermektedir. Bozkurt'a benzer fakat daha ayrnntilı bir sinfflandırma ise Herz ve Poole'e (Kerr, 2006, s. 40) aittir. Herz ve Poole oyunları Aksiyon, Dövüş, Spor, Bulmaca, Macera, Rol Yapma, Simülasyon ve Strateji gibi alt dallara ayırmaktadır. Bu dalların her biri oyunların özelliklere ilişkin fikir ve örnekler sunmaktadır.

Oyunların eğlence unsurlarından farklı olarak ciddi bir platform olarak adlandırılması askeri ve siyasi alanlarda kullanımıyla tartışılmaya başlanmıştır. Burada dikkat çeken kavramlar aslında eğitim ve propaganda olmuştur. Sorensen ve Meyer'e göre (2007) ciddi oyunlar, eğitim tasarımı ve eğlencenin ötesinde bir gündemi olan dijital oyunlar ve ekipman olarak tanımlanır. Ciddi Oyunlar, anahtar kelime olarak ayrı bir öneme sahiptir ve diğerlerinin yanı sıra, öğrenme oyunları, eğitici oyunlar, eğitim oyunları, iş oyunları ve fiziksel oyunu teşvik eden oyunları içerir ve çeşitli konuları, hedef grupları ve bağlamlan aşarlar. $\mathrm{Bu}$ açıdan ciddi oyunlar aslında insanların belirli konularda nasıl düşünmeleri gerektiğine dair şablonlar üretmekte ve bu şablonlar üzerinden işlemektedir (Bayraktutan-Sütcü, 2009, s. 315). Michael ve Chen'e göre (2006, s. 23) ise ciddi oyunlar, bir mesaj iletmek, ders vermek veya bir deneyim sağlamak için oyunların sanatsal ortamını kullanan oyunlardır.

Ciddi oyunlar eğlence oyunları ile yukarıda belirtilen özellikler açısından ayrılmaktadır. Öğrenme, eğitim, sağlık, esenlik, değişim, ikna veya burada tartışıldığ gibi, sadece deneyim veya duygu ciddi oyunların temel unsurlarını oluşturmaktadır (Marsh, 2011, s. 61). Bu açıdan bakıldığında ciddi oyunlar ile eğlence oyunlarının farklarına vurgu yapmakta fayda vardır. Susi, Johannesson ve Backlund (2007, s. 6) eğlence oyunları ile ciddi oyunları birtakım farklara göre ayırmaktadır. Bu farklardan ilki ciddi oyunların odak noktasının problem çözme olarak belirlenmesidir. Çünkü kullanım alanlarına bakıldığında aslında amaç daha çok eğitimdir. Eğlence oyunlarında ise amaç aslında deneyim elde etmektir ve burada herhangi bir ögrenim amacı bulunmamaktadır. Temel unsur eğlence üzerine kuruludur. Ciddi oyunlar aslında sistemli çalışan ve gerçekliğe yakın olan bir simülasyon üzerine işlemektedir. Eğlence oyunlarında ise bu süreç daha basit bir düzeyde çalışmaktadır. Son olarak iletişim öğesine bakıldığında ise ciddi oyunlarda mükemmel olmayan, eğlence oyunlarında ise daha mükemmel bir yapı ortaya çıkmaktadır. 


\section{Gelenekselden Dijitale Kimliğin Dönüşümü}

\section{Kimlik ve Benlik}

Bireylerin doğdukları andan itibaren hayata dair elde ettiği önemli kazanımlar sonucunda benlik yapılarının oluşma süreci başlamaktadır. Tutar’a göre (2014, s. 65) benlik, her şeyden önce, kendimize ilişkin inançlarımızın bütünüdür. Doğumdan ölüme kadar olan süreçte tecrübe edilen sayısız olay ve diğer insanlarla olan ilişkiler benlik üzerinde etkiye sahiptir. Tutar'a benzer bir başka tanımlama ise Kenç ve Oktay'a aittir. Onlara göre (2002, s. 72) benlik, yaşantılar sonucunda gelişen edinik bir yapıdır. Bir başka ifade ile benlik bireyin doğduğu andan itibaren geçirdiği yaşantıların sonucunda edinilen ve bu yaşantılarla gelişen bir yapıdır.

Doğumla birlikte başlayan dünyaya alı̧̧ma süreci aynı zamanda bireyin kendisini ve dünyaya bakış açısını belirler. Bu süreç içerisinde kişi kendisine dair anlamlandırma sürecini başlatmış olur. Hayatı boyunca yaşadığ1 tüm tecrübe ve birikimi yaşamına aktaran kişi, hem bunlardan birtakım dersler çıkarır hem de bunları kendi benliğinin bir parçası haline getirir. Bu bağlamda benliği şahsın kendisine bakış açısı, kendisini zihninde temsil ediş biçimi şeklinde tanımlamak mümkündür. Ayrıca, benlik kavramı şahsın kendisi ile ilgili algılamalarının, kişisel atıflarının (yüklemelerinin), geçmiş yaşantılarının, gelecekle ilgili hedeflerinin, sosyal rollerinin onun zihninde temsil edilissi ve zihinde kavramsal ben olarak odaklaşmasıdır (Aydin, 1996, s. 41).

İnsanların birlikte yaşamaya başlamasıyla sosyal çevre ve toplumsal yapı kavramları ön plana çıkmıştır. Tarım toplumuna geçilmesiyle sosyal birliktelik artarken kişiler aynı zamanda hem birbirlerine bağlı hem de birbirlerinin uyarı ve düşüncelerini önemseyen bireyler haline gelmiştir. Bu durum benlik kavramının oluşumuna önemli etkiler yapmıştır. Böylece benlik oluşumuna ilişkin başkalarının kişiye yansıttı̆̆1 özellikler, kişinin kendisi hakkındaki gözlemlerinden elde ettiği bilgiler gibi etkili olmuştur. Kişi kendisi hakkında sıklıkla söylenen şeyleri benliğinin parçaları olarak görür ve ifade eder hale gelmiştir (Özen ve Gülaçt1, 2010, s. 23).

Benlik türlerine baktığımızda karşımıza 5 ana başlı çıkmaktadır. Tutar'a göre (2014, s. 68-69) bu 5 ana başlık şunlardır:

- Vücut benliği: İnsanın çocukluğundan yaşlilığına kadar vücudunda yaşanan değişiklikleri anlamayı sağlayan benlik algısıdır.

- Cinsiyete ait benlik: Kişinin ergenlik döneminde vücudunda yaşadığı hızlı değişimleri fark etmesiyle ilgili benliktir.

- Sosyal benlik: Aile, arkadaş, sosyal gruplar, yığınlar, kategoriler ve toplumdaki diğer insanlarla iletişim kurma ile ilgili benlik algılamalarıdır.

- Mesleki benlik: Kişinin kendilik saygısı, mesleki saygıyla, iş ve meslek ahlakıyla ilgilidir.

- Ahlaki benlik: Tutum ve davranışlarının diğer insanları nasıl etkilediği, kendisi için istediği “iyi”yi başkası için de isteyip istemediği ile ilgili benlik algısıdır.

Benlik algısında ön plana çıkan bu yaklaşımlar kişinin toplum ve kendisi açısından öngördüğü kişilik oluşumuna dair ipuçları vermektedir. Kendisini uzun boylu yahut kısa boylu olarak tanımlayan bir kişi kendi benliğine dair yorumsama yaparken vücudunun bu özelliklerinden faydalanır. Yahut cinsiyetinin ona atfettiği birtakım özellikler, onun toplum içerisinde ne tür bir davranış kalıbına girmesi gerektiğine dair yaklaşım sunar. Mesleki ve sosyal benlik ise elde ettiği iş, statü ve davranış kalıplarını bu yönde belirlemesine uygun davranış kalıpları sunar. Ahlaki özellikleri hem kendisi hem de diğer insanlara yönelik tutum ve davranışlarını şekillendirmesinde anahtar kavramlar olarak ön plana çıkar.

Tüm bu tanımlamalar ve kategorileşmeler birlikte düşünüldüğünde kişiyi kendisi yapan en önemli özelliklerin başında benliğin geldiği ortaya çıkmaktadır. Hayatımızın her evresinde var olan benlik kavramı, insanın kimliğinin ve kişiliğinin en merkezi noktasında bulunur ve onu kendisi yapmaktadır. Bu nedenle benlik öznellik ve kimlik konularıla bağlantılıdır (Tutar, 2014, s. 66).

Kuramsal ve kavramsal açıdan bakıldığında tarih içerisinde toplumsal olayların benlik üzerinde birtakım değişiklikler ortaya çıardığı görülmektedir. Hogg ve Vaughan’a göre (2011, s. 138-139) benlik kavramı, 16. Yüzyıl'dan itibaren değişimlere uğramaya başlamıştır. Bu değişimler 4 başlık altında toplanmaktadır: 
Sekülerleşme: İnsanın tüm ümit ve beklentilerini ölümden sonraki yaşama erteleme düşüncesinin yerini, onları gerçek kılmak için bu dünyada etkin bir biçimde çaba harcanması gerektiği yolundaki düşüncenin alması.

Sanayileşme: İnsanlar artık çalışmak üzere oradan oraya hareket eden birer üretim birimi olarak görülmekteydi; dolayısıyla geniş aile gibi statik toplumsal yapılara kenetli olmaktan çımaya, taşınabilir bir sosyal kimliğe sahip olmaya başlamışlardı.

Aydınlanma: İnsanlar kendileri için farklı/daha iyi kimlikler ve yaşamlar organize ve inşa edebileceklerini düşünüyorlardı artık; bunun için de Ortodoks değer sistemlerini ve baskıcı rejimleri alaşağ1 etmişlerdi (örneğin on sekizinci yüzylın sonundaki Fransız ve Amerikan devrimleri).

Psikoanaliz: Freud'un (örneğin, 1921) insan zihnindeki işleyişine ilişkin olarak geliştirdiği kuram, benliğin gerçek anlamda anlaşılamayacağı, çünkü onun bilinçdışının bilinmedik derinliklerinde yattığı yolundaki düşünceyi berraklaştırmıştır.

Benlik değişimi üzerinde ilk dikkat çeken tanımlamalardan biri sekülerleşme üzerinedir. Modern döneme kadar gelen süreçte insanlar yaşama olan bakış açılarını dünyevi sistem üzerine değil, dini inanışlarının öngördüğü ölçüde "ahiret" inancı üzerine kurgulamaktaydı. Maddeden uzak ve dünyanın sunduğu "somut" nesnelere ihtiyaç duymayan bu bakış açısı, bireylerin benlik oluşumlarına da doğrudan etki etmekteydi. Fakat 18. Yüzyll'dan sonra başlayan aydınlanma hareketleri ile birlikte pozitivist yaklaşımların ön plana çıkışı, sekülerleşme mantığının hızlanmasına yol açmıştır. Bu dönemde insanlar diğer dünyadan ziyade yaşadıkları hayatı anlamlandırmak ve onun sunduğu nimet ve zevklerden daha fazla faydalanma ihtiyacı duyar hale gelmiştir. Böylece kişiler, benliklerinde eski kuralcı ve kabul edici yapılardan ziyade daha özgürlükçü ve maddeci bir yaklaşıma doğru evrilir hale gelmiştir.

Sekülerleşmeyle orantıllı olarak benlik değişimlerine etki eden bir diğer unsur sanayileşme olmuştur. Avrupa'da İngiltere'nin başı çektiği sanayileşme hamleleri 18. Yüzyll'da baş göstermiştir. Bu dönemde tüm dünyada büyük bir değişim süreci yaşanırken bireylerin sosyal yaşantıları da bu değişimlerden nasibini almıştır. Sanayi öncesi dönemde tarım toplumu, bireyleri birbirine daha çok bağlayan ve geniş ailelerin bir arada yaşadığı bir yapıyı oluşturmaktaydı. Daha çok kendi üretimleri için çalışan kişiler sanayi hamleleri ile birlikte fabrikalar ve büyük ölçekli şirketlere hizmet eder hale gelmişlerdir. Bu dönemde insan, bir meta haline gelerek çalışması gereken, sadece üretim odaklı görülen, göç edebilir ve farklı toplumsal yapılarla kaynaşabilir hale gelmiştir. Böylece bireyler farklı toplumların sosyal yapı ve statülerinden etkilenmişlerdir. Benlik yapıları bu sayede farklı toplumların yapı ve statülerinden faydalanır bir yapıya kavuşmuştur.

Ortaçağ Avrupa'sı her açıdan kilise etkisinin yoğun hissedildiği ve dini yaklaşımların ön planda olduğu bir dönem olarak karşımıza çıkmaktadır. Bu dönemde kilisenin mutlak hâkimiyeti kıta Avrupa'sında tekelci bir yaklaşımı ön plana çıkarmıştır. Bireyselliğin arka planda kaldığı bir dünya yapısı içerisinde her kişi, tanıının hizmetkârı ve onun yeryüzündeki temsilcisi olan kilisenin boyunduruğu altında olması gereken maddeler olarak görülmüştür. Fakat Rönesans, Reform ve Aydınlanma Hareketleri ile birlikte tüm dünyada farklı bir düşünce dalgası oluşmuştur. Özellikle 18. Yüzyıl sonunda Fransa'da yaşanan devrimle insanlar bireyselleşme yolunu seçmişlerdir. Kendileri için yaşama ve kendilerine ait bir yaşam kurma gayesi içerisine giren bireyler, benlik yapılarını da bu doğrultuda oluşturma gayesine yönelmiştir. Baskıcı rejimlerden kurtulmak için kitlesel isyanlara yönelen kişiler, pozitivizmin ön planda olduğu akılcllık perspektifinde düşünce sistemine sahip olmuştur.

İnsanların bireysel yapılarının oluşumunda etkin olan bir diğer önemli unsur kimliktir. Kimlik ve benlik ilişkisinin önemine dair yapılan araştırmalar iki kavramın birbiriyle iç içe bir yapida olduğunu ortaya koymaktadır. Bilgin, kimliğin oluşumunda benliğin önemine vurgu yapmaktadır. Ona göre (2014, s. 98) çocuklar hayatlarının ilk haftalarında etrafindakinin rollerini alarak eğlenmektedir. Sonrasında ise öğrendiği rolleri kendisine yerleştirmektedir. Bu durum sonucunda sosyal grubunu, kendi davranışlarını yöneten normların, tutumların, amaçların örgütlenmiş bir topluluğu olarak algılamaktadır.

Kimliğin oluşumunda şüphesiz ki doğuştan gelen kişilik özelliklerinin etkisi büyüktür. Fakat bunun yanı sıra toplum içerisinde yaşayan bireylerin bu yapıdan aldıkları etkileşimler de bir hayli önemlidir. Nitekim çocukluktan itibaren insanlar, çevrelerinde gördükleri her şeyden etkilenir ve onu kendi yapılarına uygun bir şekilde alarak işlerler. Çocuklarda eğlence işlevi olarak başlayan bu süreç zamanla öğrenmeye doğru yönelir. Bu öğrenme sonucunda kimlik yapıları şekillenmeye başlar.

Çocuklara yönelik yapılan araştırmalarda ayna deneyimi fazlasıyla dikkat çekmiştir. Zazzo'nun araştırmalarına göre çocuklar iki yaşına doğru aynadaki imgesini tanıyabilir hale gelmektedir. Nitekim 
çocuk kendi vücudu ile (organları, heyecanları, dokunma duyuları) aynadaki kendi imgesinin dış görünüşüyle ilişki kurduğu anda kimlik duygusunu kazanır (Bilgin, 2014, s. 103). Çocukların bu kimlik yapılarının oluşumunda ilk ve en önemli unsur ailedir. Çocuklar başlarda ebeveynlerinin tutum ve davranışlarını birebir kopyalarlar. Kendilerini bir birey olarak hissetmeleri ise genellikle kendi vücutlarını tanımaya başladıkları zamanla eş değerdir. Bu ayna sürecinde çocuklar kendi fiziki yapısı ile bir ilişki kurar ve kimlik oluşumunun ilk adımlarını atmıs olur.

Kimliğe ilişkin daha kuramsal ve kavramsal yaklaşımlara bakıldığında ortaya 4 temel unsur çıkar. Bilgin'e göre (2014, s. 84-85) bu 4 temel unsur “ayna” ben yani diğerlerinin bana yansittığı özelliklerdir. İkincisi bireyin kendisini diğerleri ile karşılaştırması. Üçüncüsü grup aidiyetlerini dile getirmek ve sonuncusu sosyal statü ile gelen rollerdir. Her birey temelde ilk olarak kendi özelliklerinden beslenir. Doğuştan gelen bu özellikler (fiziki yapı gibi) bireye bir aidiyet yapısı hissettirir. Mavi gözlü olmak, açı bir tene sahip olmak, uzun boylu olmak gibi birçok özellik kişinin ilk adımını oluşturur. Daha sonra insanlar çevresindeki kişilerle kıyas noktasına geçiş yapar. Kıyaslar aynı zamanda insanların ne tür bir çevrede var olmak istediklerine yönelik önemli ipuçları sunar. Bunun devamında ise elde edilen sosyal statü, kimlik yapılarına ilişkin veriler sunar.

Kimliğin oluşumunda bireylerin toplumsal açıdan oluşan norm ve değerlere ilişkin hareket etmeleri de son derece önemlidir. Erving Goffman, Günlük Yaşamda Benliğin Sunumu (2012) adlı eserinde kişilerin toplumda kabul gören yapılara ilişkin davranış değişikliklerinde bulunduklarını belirtmektedir. Bununla birlikte taklit, benzemeye çalışma gibi çabaların da kimlik oluşumunda etkili olduğunu ifade etmektedir. $\mathrm{Bu}$ durum kişileri kimlik yapısının oluşumunda toplumsal yapının önemine yönlendirir. Toplumsal yapı içerisinde her kişi, tek başına yaşamaya pek uygun değildir. Günümüzde bir orman yahut 1ssız adada yaşayan insan sayısı oldukça azdır. Bu da kişileri topluluk içerisinde yaşamak zorunda olan birer canlılar oldukları sonucuna ulaştırır. Bu noktada Goffman'ın yaklaşımı önem kazanmaktadır. Zira insanlar var oldukları çevre içerisinde bazen olmadıkları insanlar gibi davranmak zorunda kalabilirler. Bu durum onları zamanla var olmak istemedikleri kimlik yapılarına büründürebilir. Taklit ve benzemeye çalışma olarak adlandırılan bu yaklaşım sonucunda insanlar "bulunduklanı kabın şeklini" alarak o toplum yapısında kabul görürler. Kabul görme insanlar için son derece önemlidir. Çünkü kabul görme toplumsal yapıda var olabilmenin anahtar unsurlarından biridir.

Kimlik kavramına ilişkin bir diğer önemli yaklaşım Sosyolog Anthony Giddens'a aittir. Giddens'a göre (2010, s. 102-103) bireylerin kimlik oluşum sürecinde tarihsel dönemlerin etkisi büyüktür. Giddens, Orta Çağ Avrupa'sında kimlik oluşumunun kurumsallaşmış süreçler tarafindan oluşturulduğunu ifade etmektedir. Ona göre bu "pasiflik" modern süreçle birlikte değişmeye başlamıştır. Giddens'n burada üzerinde durduğu unsur, sosyal yapı ve yönetim anlayışlarının bireylerdeki hâkimiyetidir. Orta Çă̆ Avrupa'sında kilise temelli bir yaklaşım bireylerin yaşam tarzlarına doğrudan etki etmekteydi. Bunun sonucunda kişilerin yerine düşünen, onların yerine karar veren ve onlara belirli bir kimlik yapısı atfeden statü bulunmaktaydı. Giddens'ın pasiflik ile tabir etmek istediği nokta tam olarak buraya değinmektedir. Orta Çağ sonrası dönemde bu yapı değişimlere uğramıştır. Aydınlanma Çağı, ulus-devletçiliğin yükselmesi ve Sanayi Devrimi gibi tarihsel olaylar kimliğin yapısında önemli farkllıklar oluşturmaya başlamıştır.

Yukarıda belirtilen tüm bu sosyal yaklaşımlar kimlik tanımının farklı alanlarla olan ilişkilerini göz önüne sermiştir. Bu nedenle "kimlik" tanımı çağdaş sosyal bilimde psikanaliz, psikoloji, siyaset bilimi, sosyoloji ve tarih gibi birçok alanda kendisine yer bulmaktadır. (Stryker ve Burke, 2000, s. 284). Nitekim ABD'nin sosyo-kültürel bağlamı içinde gelişen kimlik terminolojisi, tüm dünyaya ihraç edilerek medyatik, siyasal ve sosyal vokabülere nüfuz etmektedir. Günümüzde kimlik kavramı, milliyetçilik, göç, din, cinsiyet araştırmaları ve etnisite araştırmalarında neredeyse vazgeçilmez bir hale gelmiş durumdadır (Bilgin, 2014, s. 21). Sonuç olarak kimlik, birbiriyle ilişkili birçok toplumsal ve sosyal olayla bağlantılı bir tanımdır. Jenkins (2014) bu durumu “insanın 'kim' olduğunu, diğerlerinin sizin kim olduğunuzu bilmesi ve diğer insanların bizim kim olduğumuz hakkında düşünmesidir” şeklinde yorumlamaktadır.

Klasik anlamdaki kimlik tanımının yanı sıra gelişen yeni medya ve internet teknolojileri bireylerin yeni bir kimlik yapısı yani "dijitali" oluşturmalarına olanak sağlamıştır. Özellikle sosyal ağlar çerçevesinde gelişen yeni kimlik yapısı bireylere birtakım sosyal ve psikolojik nitelikler kazandırmışır. Bu bağlamda ortaya hem pozitif hem de negatif olan bazı kavramlar çıkmıştır.

İnternet teknolojilerinin gelişmesi bireylerin yaşam safhalarında birçok farklı değişimi getirmiştir. Dijitalleşmeyi hayatın her noktasında hissetmeye başlayan insanlık, kimlik yapılarında da birtakım 
yeniliklerle karşı karşıya kalmışıtır. Klasik anlamda yapılan kimlik tanımlamaları insanların benlik ve özlük ilişkilerine gönderme yaparken, dijitalleşen kimlik bunlara ek olarak kişilerin oluşturdukları yeni sanal yapılara ve değişimlere işaret etmektedir.

Dijital kimliğin oluşumuna yönelik birçok farklı fikir ve düşünce ortaya atılmıştır. Bunların en önemlilerinden biri Spears ve Lea'nin (1994) ortaya koyduğu SIDE (Social Identity Model of Deindividuation Effects) teorisidir. Sosyal kimlik ve kimliklerin belirsizliği üzerine kurulan bu teoride bilgisayar ortamlı iletişimde hedef; benlik, kimlik ve gruplar arası iletişimi ortaya koymak olarak belirlenmiştir. Burada Spears ve Lea'nin ön plana çıarmak istedikleri birtakım temel unsurlar yer almaktadır. Anonimlik ve kimlik belirsizliği üzerinden oluşan yeni dijital kimlik yapılarına gönderme yapan Spears ve Lea, kişilerin yeni dijital kimlik yapısı içerisinde her geçen gün öz kimliklerinden uzaklaştıklarını ve içerisinde bulundukları grubun normlarına uyum sağlamaya başladıklarını ifade etmektedir. Bu teoride ön plana çıkan bir diğer unsur insanların yüz yüze iletişimden uzaklaşmaları ve bununla birlikte mekânsal ve zamansal bir izolasyonun içerisinde yer almalarıdır. Bu izolasyon süreci dijital kimlik unsuru ile doğrudan bağdaşmaktadır. Zira izolasyonla birlikte var olan anonimlik aynı zamanda bireyleri özgür kılmaktadır. Bu özgürlük sayesinde bireyler istedikleri türde bir kimlik yapısını tesis edebilmektedir.

Bireylerin oluşturdukları anonim yapı içerisinde dijital bir kimlik safhasının izdüşümü olarak profiller, kişilere büyük bir kolaylık sağlamaktadır. Bu sayede dijital kimliği oluşturmak son derece basitleşirken kişilerin yaş, cinsiyet gibi bilgileri paylaşmak zorunda kalmamaları sanal kimliklerini istedikleri gibi şekillendirmelerine olanak vermektedir. Bu bağlamda düşünüldügünde mecralar, bireyin yeniden kimlik üretmesine imkân veren ve mevcut yarattığı dijital kimlikleri ağ tabanında saklayan bir sistemi barındırır (Sarıyar, 2019, s. 30). Yeniden üretilen kimlik safhas1, bireylere olmak istedikleri kimlik yapısına yönelik ipuçları sunar. Öyle ki uzun yıllar boyunca hayal ettikleri bir kişiliğe yahut kimliğe ulaşmak isteyen bireyler, birçok sorumluluktan kurtulmuş olurlar. Bu sayede bireyler aile, sosyal sınıf, cinsiyet, coğrafi bölge gibi etmenlerin getirdiği grup kimliklerinin yükümlülükleri de dijital kimliklerde taşımak zorunda kalmazlar. Dolayısıyla dijital kimlikler kişilerin gerçek hayatta sahip olmadıkları seçenek ortamını sunmaktadır (Gündüz, 2014, s. 65).

Kişilere sunulan yeni kimlik yapılarının tesis edilmesinde sosyal ağların rolü büyüktür. Birçok özelliği ile sosyal ağlar bireylere hem birtakım kazanımlar sunmaktadır hem de bazı problemlere neden olmaktadır. 2000’li yıllarda hızla gelişen internet teknolojisi bireylerin birbirleri ile olan iletişim ağlarını güçlendirmiştir. Önce Web 1.0, sonrasinda Web 2.0 farklı alternatifler sunarken Google, YouTube ve Facebook gibi sosyal medya mecralarının var olması insanların deneyimlerini diğer kişilerle paylaşmalarına olanak sağlamıştır. Diğer yandan bu mecraların ortaya çıkışı farklı cemaat ve grupların oluşmasına ön ayak olmuştur.

Sosyal ağlar ile günümüzde bireyler, her türlü iletişimi sağlayabilmektedir ve birbirlerine ait bilgilere sahip olabilmektedir. Fakat burada oluşan durum daha çok bireyin kendisini ne şekilde sunduğu ile bağlantılıdır. Zira sosyal ağlar üzerinde bireylerin kendilerini istedikleri gibi sunabilme özellikleri bulunabilmektedir. Bununla birlikte kişiler oluşturdukları profiller üzerinden yeni bir kimlik sunumu yapabilmektedir. Bakıroğlu'na göre (2014) bireyler, oluşturdukları bu profiller aracıllğıyla fotoğraflar, paylaşımlar yapmaktadır ve bunların tümü bireyin oluşturmak istediği kimliğinin bir parçasıdır.

Sosyal ağlar aracıllğ̆yla kimlik edinme süreçleri kişilere birçok farklı özgürlük sunmaktadır. Bireylerin çevrim içi ortamlarda fiziksel yönlerini göstermek zorunda olmamaları onlara aynı zamanda birtakım ayrıcalıklar sunmaktadır. Bu bağlamda düşünüldüğünde çevrim içi mekânlarda görünür bedenlere sahip olmamak, katılımcılara kendi temsillerini ve nasıl tanınmak istediklerini aktif olarak yapılandırmaları için birçok imkân sunmaktadır (Cizmeci, 2014, s. 393). Bu imkânlar bazen istedikleri dijital kimliği oluşturmalarına izin verse de çoğu zaman kişiler uzun vadeli paylaşımlarda öz kimlik yapılarını ortaya koymaktadır. Örneğin, bir çevrim içi tartışma sitesinde belirli bir takma adla ilişkilendirilen itibar, çevrim dışı kimlikten bağımsız olarak sunulabilir. Fakat sonuç olarak bakıldığında bireyin kendini görünür kılmak için bir dijital kimlik oluşturması gerekmektedir (Ellison ve Boyd, 2013, s. 4).

Oluşturulmak istenen dijital kimlik yapısında içerisinde bulunulan ortamın etkisi büyüktür. Boyd'a göre (2007, s. 13) bireyler bazı zamanlarda kimliklerini bulundukları ortama göre inşa ederler. Bunun temel sebebi bireylerin girdikleri ortamda var olabilme ve kendilerini kabul ettirebilme dürtüleridir. Bunun benzeri dijital ortamda da kendisini göstermektedir. Örneğin bir MySpace profili, bireyin kendisini sunabileceği bir dijital beden biçimine dönüşebilmektedir. Sonuç olarak ne olursa olsun bireylerin dijital ortamlarda var olma hisleri ortaya çıkmaktadır. Böylesi bir ortamda bireyler "dijital bedenlerini" bir var olma aracı olarak kullanmaktadır. İnsanlar, internet ortamında her ne kadar coğrafi koordinat ve yaşanılan 
yer gibi bilgilere ulaşamasa da bireylerin kendi elleriyle sundukları bu dijital bedenlere bir tuş kadar yakındırlar (Boyd, 2007, s. 9).

Dijital kimlik yapılarının oluşumunda kabul görülen yeni simule evrenin katkısı büyüktür. Baudrillard'n ortaya attığı simülasyon evreni kavramı kişilerin zamanla kendilerini gerçek olmayan dünyanın bir parçası haline getirmeleri üzerine kuruludur. Bireylerin sosyal ağlar vasıtasıyla elde ettikleri sanal kimlikler de bu kavram ile doğrudan örtüşmektedir. Günümüzde Second Life gibi yahut çevrim içi olarak oynanan çok sayılda bilgisayar oyununda görüldüğü gibi bireyler kendilerini bir grubun ve hayatın parçası halinde görebilmektedir. Öyle ki zamanla bu grubun sadık birer üyesi haline gelirler ve orada kendilerine yeni bir sanal yaşam inşa edebilirler. Bu sanal yaşam içerisinde gündelik hayattan uzaklaşan bireyler, zamanla bu grupları sosyal yaşamlarının bir parçası haline getirebilmektedirler (Bargh ve McKenna, 2004, s. 12).

\section{Dijital Oyunlarda Avatar ve Kimlik}

Yeni medya teknolojilerinin gelişmesiyle bireylerin yaşadığı birtakım sosyal ve psikolojik değişimler, dijital oyunlar aracılığıyla gücünü arttırmıştır. 1990'lı yıllarda Web 1.0'1n ortaya çıkmasıyla değişen sosyal ilişkiler insanların kimlik edinim süreçlerini de etkilemeye başlamışır. Konuya ilişkin çok sayıda çalışma yapan sosyolog Sherry Turkle'ye göre (2005, s. 132) ergenlikle birlikte kişiler kimlik oluşturma sürecinde birçok farklı materyalden faydalanmaya başlamıştır ve bilgisayarlar sosyalleşme ve kimlik oluşturmada önemli bir araç haline gelmiştir. Buna bağlı olarak gelişen teknolojiyle birlikte oluşan kişisel web sayfalarının da kimlik yansıması olduğunu belirten Turkle (1997, s. 258) kişilerin sayfalarında ilgi duydukları müzik, resim, fotoğraf benzeri içerikleri paylaşarak kimlik oluşturduklarını ifade etmektedir.

1997 yilında yazdığ "Life on the Screen Identity in the Age of Internet" adlı kitabında dijital oyunlarkimlik ilişkisine değinen Turkle, bir grup öğrenci ile gerçekleştirdiği görüşmede deneklerin çevrim içi oyunlar aracilğ̆ıla oluşturdukları sanal kimliklerinin çevrelerindeki insanlara kendilerini tanıtmada büyük yardımları olduğuna dikkat çekmektedir (1997, s. 256). Bu açıdan bakıldığında dijital oyunların insanların çevreleri ile olan ilişkilerini düzenlemede önemli bir rol oynadığı görülmektedir. Nitekim Turkle (1997, s. 265) dijital oyunların kolektif kimlik duygusunu yeniden şekillendirdiğini ifade ederek kişilerin kimliklerini yansıtmada bu platformdan faydalandıklarına dikkat çekmektedir.

Dijital oyunlar aracıllı̆ıyla yaratılan kimlik tartışmalarında en çok dikkat çeken kavramlardan biri "persona” olmuştur. Binark ve Bayraktutan-Sütcüye göre (2008, s. 57) sanal uzamda yaratılan ve dijital oyun dünyasında performe edilen kimlik son kertede, bireyin "persona"sının bir uzantısıdır. Bartle’ye göre (2001) ise persona oyuncu-gerçek ayrımının sona erdiği ve oyuncunun bizatihi karakterin kendisinin olduğu bir kavramdır. Ortada herhangi bir dolayllık yoktur ve oyuncu karakteri öldügünde aslinda kendisinin de öldügünü hissetmektedir. Yani personalar her ne kadar sanal bir düzeyde kişilerin hayatına girse de zamanla bu sanallık yerini Boudrillard'ın da işaret ettiği hipergerçeklik'e bırakmaktadır. Dolayısıyla birey bu dünyayı gerçek olarak kodlamaktadır.

Personalar aracıllğıyla oluşan kimlik inşası sürecinde özdeşleştirmenin rolü son derece büyüktür. Batt'ya göre (2011, s. 21) özdeşleşmeyle birlikte kişi kendisini yapaya doğru yönlendirmektedir ve kişinin yeni bir kimlik süreci başlamaktadır. Kişinin hayatında yaşadığı yeni duygular, heyecanlar ve yaşanmışlıklar da bu kanıyı desteklemektedir. Baym'a göre (1998, s. 55) ise bu özdeşleşme süreci tutarll1ık içerisinde gelişmektedir. Çünkü çoğu sosyal kullanıcı dijital alanlarda çevrim dışı kimlikleriyle tutarlı bir çevrim içi benlik yaratmaktadır. Bu benlik ve kimlik yaratımıla birlikte bir yandan yeni mekânlar ve roller oluşturulurken (Waskul ve Douglass, 1997 Akt: Soyseçkin, 2007, s. 252) diğer yandan kişiler kendilerine hile yoluyla "ideal" dünyalar yaratarak (Tetir, Kıliç ve Topcu, 2020, s. 19) gerçek sorunlardan kaçş yolunu seçebilmektedir.

Dijital oyunların kimlik inşası sürecinde $90^{\prime} l ı$ yıllarda son derece etkili olan ve üzerine birçok farklı çalışma yapilan Multi-User Dungeon (Çok Kullanıcılı Zindan) oyunu önemli bir yere sahiptir. Kısaca MUD olarak aktarılan bu oyun, bir bilgisayar ağı üzerinden birkaç eşzamanlı kullanıcıdan gelen bağlantıları kabul eden ve onlarla veri paylaşımına izin veren bir programdır. Bu ortamda bireyler metinsel düzlem üzerine kurulu sanal odalar arasında dolaşarak birbirleriyle etkileşime girebilmektedir (Bartle, 1999). Curtis ve Nichols'a göre (1994, s. 193) MUD kullanıcıları, genellikle aynı odadaki diğer tüm kullanıcılar tarafindan görülen mesajları yazarak, birbirleriyle gerçek zamanlı olarak doğrudan iletişim kurmaktadır. İlk MUD geliştiricilerinden Richard Bartle, bir MUD’a dalmanın üç düzeyinden bahsetmektedir. İlk aşama olan 
"avatar"da sanal yaratık sadece emirleri yerine getirmektedir. İkinci aşamada karakter oyuncunun bir uzantısını yani onun oyun dünyasındaki temsiliyetini temsil etmektedir. Üçüncü aşamada ise karakter ile duygusal bir bağ kurulmaktadır ve bu persona durumu ile birlikte oyuncu avatarı ile duygusal bağ oluşturarak doğrudan oyundaki hayatın bir parçası olmaktadır (Fidaner, 2009, s. 233).

MUD'lar ve sanal kimlik ilişkisi üzerine çok sayıda çalışması olan Sherry Turkle'ye göre (1997, s. 1114) MUD'lar, sanal kimliğin inşasına yönelik çarpıcı bir örnektir. Zira kişiler MUD’lar aracillğıyla sohbet edebilecekleri, keşfedebilecekleri hatta inşa edebilecekleri yeni sanal ortamlar elde etmektedir. Bu inşa süreci zamanla bireylerin yaşamında birincil bir rol elde ederek hayatlarını doğrudan etkilemektedir. Çünkü MUD’lar aracılığılla sanal ile gerçek arasındaki ilişki bulanıklaşmaktadır ve benlik, rol ve simülasyon gibi birçok kavram iç içe geçmektedir (Turkle, 1996, s. 157).

Turkle, MUD’lar aracillğıyla oluşan sanal kimliklerin zamanla kişilerin "gerçek” ilişkilerini etkilediğine dikkat çekerek Ava adlı bir karakterin bedensel engeline rağmen sanal kimliğine aşık olan bir kişi ile ilişkisini gerçek hayata evrilttiğini belirtmektedir (1997, s. 263). Bir başka örnekte ise Fidaner, Orta Doğu Teknik Üniversitesi'ndeki MUD oyuncularının oyun içindeki karakter yapılarına göre arkadaşlık kurduklarını ve oyunun içinde yanına yaklaşılmayanların gerçek hayatta da ayı bir sosyal gruplaşma oluşturduklarını belirtmektedir (Fidaner, 2009, s. 238). MUD’lar aracillğıyla oluşan bu hiyerarşik yap1 birtakım eleştirilere neden olmuştur. Turkle'ye göre (1996, s. 157-158) MUD’lar geleneksel anlamdaki kimlik tanımının alını oymaktadır. Çünkü kimlik, kişi ile kişilik arasındaki ilişkiye işaret ederken MUD’larda kişi birden çok kişiliği temsil edebilmektedir. Dolayısıyla MUD’ların sunduğu çoklu kimlik inşası sayesinde insanlar hem kendi kimliklerini yaratma hem de yeni kimlikleri deneyimleyebilme konusunda usta olmaktadır.

Dijital oyunlar-kimlik ilişkisinde dikkat çeken bir diğer kavram avatardır. Kökeni Hindu felsefesine dayanan avatar kavramı "kişiliğin görsel temsili" anlamında kullanılmaktadır (Doğu, 2009, s. 256). Avatarlar, kişilerin kimlik temsiliyetlerini dışa aktarmalarında önemli bir araçtır. Çünkü kullanıcılar avatar seçimini genellikle kendi imaj ve beklentilerine göre seçerek özelleştirmektedir (Teng, 2017, s. 601). Avatarların oyunlarda kullanımıyla birlikte kimlik tartışmaları daha fazla ön plana çıkmışır. Oyunlar, kullanıcılara birçok farklı avatar inşa etme hakkı tanımıştır ve bu avatarlar ile kullanıcılar karakterleri istedikleri formlara sokabilme şansına sahip olmuştur (Waggoner, 2009, s. 9-11). Hatta zamanla oyuncular avatarlar gibi düşünerek onlarla özdeşleşmeye başlamışırı (Nørgård, 2011, s. 3).

Avatarların oyunlar aracılığılla gerçekleştirdikleri kimlik inşası kişilere farklı kimlik yapılarını keşfedebilme olanağı sağlamaktadır (Dong, Liau ve Khoo, 2013, s. 9). Suh, Kim ve Suh'a göre (2011, s. 715) ise insanlar avatarlarla ilişkili olarak kimlik inşa etmektedir ve bu avatarlar tıpkı insanlar gibi bir kişiliğe sahiptir. Bu açıdan düşünüldügünde avatarların her biri sosyo-kültürel arkaplanlara sahiptir ve bireye kendini bu mecra ile ifade etme olanağı sağlamaktadır (Doğu, 2009, s. 256).

Tarihsel süreçte bakıldığında kullanıcıların avatarlarını değiştirmelerine izin veren ilk oyun Quake'dir. $\mathrm{Bu}$ oyunda kullanıcılar birçok farklı tene sahip karakterleri kullanabilmektedir (Waggoner, 2009, s. 8). Quake'in sistemli ilk avatar kullanılan oyun olmasına karşın avatar-kimlik ilişkisinde en çok dikkat çeken oyun Second Life olmuştur. Üç boyutlu bir grafik ortamı olarak geliştirilen Second Life, internet üzerinden kişilerin avatar oluşturmasına ve bu avatar aracılığıyla gündelik yaşamda gerçekleşen birçok etkileşimi yerine getirmelerini sağlamaktadır (Mitra ve Golz, 2016, s. 4).

Second Life’ta temel olarak kullanıcılara gerçek hayatta sunulmayan çok sayıda özellik verilmektedir. Kullanıcılar oyun içerisinde istedikleri cinsiyeti seçebilen, hayatlarını belirledikleri kurallar çerçevesinde düzenleyebilen yapıya sahiptir. Oyunda kişinin temsili avatarlar aracıllğıyla gerçekleştirilmektedir. Avatarların görünümü, gerçekçi insansılardan fantastik yaratıklara kadar tamamen özelleştirilebilmektedir ve bu avatarlar, arazi üzerinde uçabilme ve büyük mesafeler boyunca ışınlanabilme gibi yarı tanrı güçlerine sahiptir. Avatarların hiçbir zaman yiyecek veya içeceğe ihtiyacı yoktur ve World of Warcraft gibi birçok rol yapma oyununda olduğu gibi yaralanma veya "öldürülme" olay1 gerçekleşmemektedir (Clark, 2011, s. 147). Second Life'ta bireylerin oluşturdukları kimlikler aynı zamanda onlara yeni birer "sanal beden" temsiliyeti sunmaktadır. Avatarlar aracilığıyla oluşturulan bu kimlikler zamanla bireylerin sanal bedenlerine dönüşmektedir. Bu sayede bireyler oluşturulan bu dünyada istedikleri her türlü deneyimi gerçekleştirebilme şansına sahip olmaktadır (Jones, 2006, s. 26).

Oyuncuların sanal dünyada elde ettikleri yeni kimliklerin kısa süre içerisinde etki göstermesi ve kişilerin bu kimliklere ait güçlü aidiyetler hissetmesinde sanal ortamlarda oluşan toplulukların payı 
büyüktür. Bourdieu'nun çalışmalarında sistemselleştirdiği habitus kavramı bu konuya dikkat çekmektedir. Bourdieu'ya göre (1995: 23) habitus bir konumun içkin ve bağıntısal özelliklerini birlikçi [üniter] bir yaşam stilinde, yani insanların, malların/varlıkların, pratiklerin tercihindeki birlikçi bir bütünde dile getiren can verici ve birleştirici kökendir. Bir diğer tanımlamaya göre habituslar alanların yapısal/nesnel karakterlerinin özne tarafindan içselleştirilmesi, pratikler olarak dışsallaştırlmasıdır (Etil ve Demir, 2014, s. 339).

Habituslar sayesinde bireyler bedenlerinde içselleştirdikleri ve kabul ettikleri varoluş süreçleri içerisinde kendilerine ait kalıcı habituslar yaratırlar. Bu habituslar ile bireyler ileriki yaşamlarına ilişkin birtakım kurallar silsilesini hayatlarına yerleştirirler ve bunları sistemli bir şekilde kullanırlar. Kişilerin hayatlarındaki habituslar aynı zamanda oyunlar aracılı̆̆ıla var olan dünyalarında da kendisini göstermektedir. Sanal dünyalarda kendilerine yeni kimlikler yaratan bireylerin bu denli hızlı ve kolay bir şekilde sürece entegre olmalarında oluşan dijital habitusların payı büyüktür. Bu nedenle oyuncular gündelik yaşamda aile çevresinde, arkadaşlık ağlarında, okul ve iş yaşamında edindikleri özelliklerini ve kazanımlarını, özellikle devasa çevrim içi oyunlarda kullanmakta bir başka deyişle çevrim dışı habituslarını çevrim içinde yeniden konumlandırmaktadır (Binark ve Bayraktutan-Sütcü, 2009, s. 277).

Oyuncunun sanal uzamdaki habitus'u, oyuncunun gerçek yaşam-sanal uzam arasındaki geçişlerini ve diğger oyuncularla kurduğu toplumsal ilişkileri de belirlemektedir (Binark ve Bayraktutan, 2011, s. 306). Bu sayede oyuncular çevrim içi oyunlarda oluşturulan habituslar ile kendi iç kurallarını oluşturmaktadır ve kendi kahramanlarını yaratarak fiziksel dünyadaki duygu, düşünce ve streslerini oyun içerisine taşımaktadırlar (Kepenek, 2020, s. 204).

Bireyler, dijital oyunlar aracıllğıyla oluşturdukları habituslarla aynı zamanda sanal statüler elde etmektedir. Sanal dünyada dijital habitusunu inşa eden bireyler (Güzel, 2016, s. 94) aynı zamanda klanlara dâhil olarak (Yurdam, 2018, s. 77) kimlik yaratım süreçlerini daha geniş bir topluluğa yaymaktadır. Örneğin çevrim içi oyunlarda oluşturulan klanlarda oyuncular aynı etnik kökenden geliyorsa, üye oyuncular arasında etnik kimlik ortaklığının sergilenmesi üzerinden kimlik dayanışması oluşmaktadır ve klan üyeleri çevrim içi grup ilişkilerini gerçek yaşama da aktarmaktadır (Binark ve Bayraktutan-Sütcü, 2009, s. 281). Bu sayede bireyler oluşturdukları sanal kimliklerini bir üst noktaya taşıyarak ulus-kimlik benzeri bir kimlik süreci inşa etmekte ve bunu uluslararası arenada bir üst kimlik olarak sunmaktadır.

Dijital oyunlar kimlik ilişkisine yönelik üzerinde durulması gereken son önemli unsur Goffman'nn dikkat çektiği performans kavramıdır. Goffman'a göre (2012, s. 33) performans bir kimsenin belli bir gözlemci kümesi önünde sürekli bulunduğu bir süre boyunca gerçekleştirdiği ve gözlemciler üzerinde biraz da olsa etkisi olan faaliyetler olarak adlandirlmaktadir. Performans ile bireyler bir dizi eylem meydana getirmektedir. Bu eylemler genellikle bireylerin seçtikleri bir vitrinde ya da başka bir ifadeyle bulundukları vitrinin mahiyetine uygun bir hareketle gerçekleştirilmektedir (Gülsoy, 2017, s. 100).

Goffman'ın performans kavramını dijital oyunlar üzerinden değerlendirmek gerekirse platformlarda yaratılan performansın ve oluşturulan sanal kimliğin bireyin personasını yansıttığ söylenebilmektedir (Binark ve Bayraktutan, 2011, s. 306). Çünkü sanal uzamda ortaya koyulan avatarlar aracillğıyla bireyler bir dizi eylemde bulunmaktadır. Bu performanslar aracillğıyla oyuncular sanal dünyadaki diğer oyuncuların zihinlerinde kendisi hakkında bir izlenim yaratmaktadır (Binark ve Bayraktutan, 2011, s. 306). Tipkı gerçek dünyada olduğu gibi bu performanslar neticesinde bireylere yönelik kanaatler oluşmaktadır ve bu kanaatler neticesinde kimlik ve kişilik belirlenimleri yaratılmaktadır.

Kişilerin yaşamlarında oluşan kimlik yapıları sadece doğuştan gelen özelliklerinden ibaret değildir. Yaşam boyunca elde edinilen tecrübeler, insanlarla kurulan ilişkiler ve daha birçok sosyal etmen kimliğin oluşmasında etkilidir. Dijital oyunlar aracılığıyla oluşturulan sanal evren de kişilerin yaşamlarında var olan değişikliklere ve oluşan sanal kimliklere ilişkin birçok ipucu sunulmaktadır. Bu açıdan bakıldığında dijital oyunların oluşturduğu yeni evrende kişilerin sahip oldukları yeni "sanal" kimlikleri onlara hem kendilerini ifade etme hem de diğer bireylerin onlara ilişkin bir kanaat oluşturmasında etkili olmaktadır. 


\section{Yöntem}

Ele alınan çalışma avatarlar ile gerçek yaşamdaki kimliklerin nasıl bir ilişki içerisinde olduğu sorusu üzerinden kurgulanmıştır. Odak grup görüşmesi "nasıl” sorusu üzerinden yürütülen çalışmalarda derin ve detaylı bir bilgi sunarak katılımcıların fikirlerine ulaşılmasını sağlamaktadır. Bu bağlamda her bir örneklem çalışmanın amacına uygun olarak verileri karşılaştırma imkânı vermektedir. Çalışmanın amacına ve nasıı sorusuna cevap bulabilmek adına nitel bir araştırma yöntemi olan odak grup görüşmesi kullanılmıştır. Katılımcıların fikirlerinin alındığı ve verilen yanıtlar doğrultusunda çalışmaya uygun örüntülerin kurulması açısından odak grup görüşmesinin çalışmaya zenginlik katacağı düşünülmektedir.

\section{Çalı̧̧manın Amacı}

Günümüzde Steam ve Play Station Store gibi birçok dijital oyun platformu aracillğıyla dijital oyunlarda oluşturulan avatarlar için satın almalar yapılmaktadır. Bu satın almaların avatarlara görsel katkı sağlayan unsurlar sunmasına karşın, başka bir avantaj sağlamaması oyuncuların bu mecralarda niçin satın alma gerçekleştirdikleri soru işaretini gündeme getirmektedir. Bu açıdan bakıldığında dijital oyunlarda var olan avatarların kişilerin gerçek yaşamlarındaki kimlik yapılarına ne ölçüde sirayet ettiği önemli bir sorun olarak karşımıza çıkmaktadır. Bu bağlamda çalışma sorusu "Dijital oyunlarda belirlenen avatarlar kişilerin gerçek yaşamdaki kimlikleri ile nasıl bir ilişkiye sahiptir?" olarak belirlenmiştir. Çalışmanın amacı ise kullanıcıların seçtikleri avatarların kişilerin kimlik ve benlik yapısı üzerinde ne tür etkiler oluşturduğunu ortaya çıarmaktır.

\section{Evren - Örneklem}

Çalışmada örneklem olarak Yalova Üniversitesi Sanat ve Tasarım Fakültesi İletişim Sanatları 3. sınıf öğrencileri (SK ve SE) ve Yalova Üniversitesi Mühendislik Fakültesi Bilgisayar Mühendisliği 4. sınıf öğrencileri (ME) seçilmiştir. İletişim Sanatları öğrencileri sosyal bilimleri, Bilgisayar Mühendisliği öğrencileri fen bilimlerini temsil etmektedir. Öğrenciler amaçlı örnekleme/ kartopu örnekleme yöntemi ile evrenden seçilen 12 öğrenciden oluşmaktadır.

Amaçlı örnekleme zengin bilgiye sahip olduğu düşünülen durumların derinlemesine çalışılmasına olanak vermektedir $\mathrm{Bu}$ anlamda, amaçlı örnekleme yöntemleri pek çok durumda, olgu ve olayların keşfedilmesinde ve açıklanmasında yararlı olur (Yıldııım ve Şimşek, 2016, s. 118). Çalışmanın ana sorusu "nasıl bir etkiye sahiptir?" kavramı üzerinden yürütülmektedir. Bu nedenle ayrıntllı ve derinlemesine bir araştırma yapmak ve zengin bilgi elde etmek için nitel yöntem olan amaçlı örneklem metodu seçilmiştir. Amaçlı örneklemin alt yöntemi olan kartopu yöntemi ise üniversite öğrencileri arasında oyunları oynayan kişileri bulabilmek için seçilmiştir. Her iki bölümden de bulunan birer öğrenci üzerinden çalş̧manın amacına uygun olan diğer öğrencilere ulaşılmıştır.

Öğrencilere ilişkin sosyo-demografik bilgiler Tablo 1'deki gibidir.

Tablo 1. Ögrencilerin Sosyo-Demografik Bilgileri

\begin{tabular}{ccc}
\hline Takma Ísim & Yas & Cinsiyet \\
\hline SK-1 & 22 & Kadın \\
SK-2 & 25 & Kadın \\
SK-3 & 21 & Kadın \\
SE-1 & 23 & Erkek \\
SE-2 & 23 & Erkek \\
SE-3 & 23 & Erkek \\
ME-1 & 23 & Erkek \\
ME-2 & 23 & Erkek \\
ME-3 & 23 & Erkek \\
ME-4 & 22 & Erkek \\
ME-5 & 23 & Erkek \\
ME-6 & 23 & Erkek \\
\hline
\end{tabular}




\section{Bulgular ve Yorum}

Çalışmada öğrencilere;

- "Dijital oyun oynarken avatar seçiminde dikkat ettiğiniz unsurlar nelerdir? Sizce hangi özellikler ön plana çıkmaktadır?"

- "Avatar seçiminde kendinizi nasıl bir karakter olarak tanımlamaya çalışıyorsunuz?"

- "Dijital oyunlarda seçtiğiniz avatarların gerçek yaşamdaki kimliğinizi ne ölçüde yansıttığını düşünüyorsunuz?”

- "Gerçek yaşamda sergilemediğiniz/sergileyemediğiniz davranışları dijital oyunlardaki avatarlar aracıllğıyla ne ölçüde yansıtabilmektesiniz?” soruları yöneltilmiştir.

\section{Avatar Seçiminde Benzetme ve Hayal Etme Arzusu}

"Yaşam simülasyonu oyunlarm fazlaca oynuyorum. Avatar segiminde daba çok kendime benzeyen karakterleri tercih ediyorum. Yani kendime benzetmeye çalsşyorum. Dıs görünüs olarak ise kendimde olmayan özellikleri avatarma ekliyorum. Mesela kendimde çil olmasin çok isterdim ve karakterime bunu ekleyebiliyorum” (SK-3).

"Oyunlarda avatar seciminde kendime benzeyen karakterlere yönelmeyi seviyorum. Bunun dişında bașar odakh düşünen biriyim. Dolayısıyla ber zaman beni bașaryy götürecek avatarlar seçerim” (ME-6).

Çalışmada altı katılımcı avatar seçiminde karakterleri kendilerine benzetme hususuna önem verdiklerini belirtmektedir. Benzetme konusunda en çok dikkat çekilen kıstaslar karakterlerin güçlü ve dayanıklı olması, dış görünüşe önem verilmesi ve başarı olmuştur. Katılımcıların benzetme konusuna bu denli önem vermelerinin temel sebebinin sürekli zaman geçirdikleri sanal karakterin başarısı ile kendilerini özdeşleştirme yoluna gitmeleri olduğu düşünülmektedir.

"Ben oynadiğım oyunlarda sokăğ yansıtan, anarşist, aykırn givim kusam olan, sokakta çatıs̆maya giren ve özellikle kadın olan avatarlar seşiyorum. Marjinal ve güçlü olan avatarlar daba çok boșuma gidiyor” (SK-1).

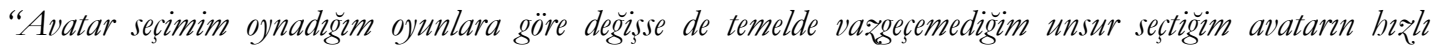
olmasıdrr. Çünkü sectiğim oyunun özelliklerini bilmesem bile bu karakterlerin daha güclü ve dayanıkl olduğunu düsïnüyorum. Ne kadar çevik olursak bana göre oyunlarda o kadar daba başarll oluruz: Bu nedenle avatar seçiminde başar odakh hareket etmekteyim. Her zaman basar getirecek, avatarlarn seçerim” (SE-1).

Katılımcılardan beşi verilen yanıtlarda hayal etme olgusunu ön plana çıkarmıştır. Avatarları yaratım sürecinde hayal ettikleri tip ve karakterleri dizayn eden katılımclar genellikle kendilerinde var olmasını diledikleri özellikleri avatarlara tanımlamaktadır. Katılımcılar bu durumu bașarı ve beğeni sıfatları üzerinden değerlendirmektedir.

"Avatar seçiminde özelliklere coke fazla takılmyyorum. Oynadiğım oyun türüne göre tercib yapıyorum ama avatarlarn oyunlara çok fazla özellike kattı̆gm da düş̈̈nmüyorum" (SE-2).

Bir katılımcı avatar seçiminde özelliklere önem vermediğini belirtmektedir. Katılımcı bu düşüncesine temel dayanak olarak avatarların oyunlarda çok fazla bir katkı sağlamamasını göstermektedir.

\section{Anonimlik, Grup Aidiyeti ve Liderlik}

"Oyunlarda destekleyici bir karakter olarak yer almak boşuma gidiyor. En iyi bildiğim avatar secmek benim icin daha rabatlatuc oluyor. Hakarete maruz kalmake can sikecc. Hele bir de cinsiyetiniz anlassliyorsa kadinlara genellikle hep ağrr sözler kullanulyyor. Biraz çekingen olmamdan ve kadinlarn bu oyunlarda ažnlikta olmasindan dolay ben kendimi daha garantici bir karakter olarak tanmlamayn seviyorum" (SK-2).

"Oyunun bikâyesine bağh bir avatar seçiyorum. Kendi duygularmla hareket ediyorum. Bu nedenle avatar seşiminde oyunun bikâyesine bağhl ve bir durusu olan karakterleri segmeyi seviyorum” (ME-5).

Katılımclardan ikisi avatar seçimi sırasında anonimliğe önem verdiklerini ifade etmektedir. Bu durumun temel sebebi oyun içinde yapılabilecek herhangi bir yanlış karşısında diğer oyuncuların tepkilerinden kaçınmadır. Oyuncuların, oyunu bu denli ciddiye almaları ve anonim bir yapıya sahip olmak istemeleri var olan sanal dünyayı önemsedikleri ve kendilerini oraya ait hissettikleri sonucunu ortaya koymaktadır. 
"Nişan alma gücü yükesek olan, seri karakterlere bürünmek hoşuma gidiyor. Takım arkadaslarma bilgi ve destek vermek bana güzel geliyor. Yani destek veren, çatısmalar uzaktan yöneten bir karaktere bürünmeyi tercih ediyorum" (SE-1).

"Oyunlarda rakibine hasar verebilen ve öldürebilen avatarlar tercib ediyorum. Çünkï takerm arkadaslarm tarafindan eleștirilmekten korkuyorum. Bir oyunda yeterli performans gösteremęsseniz aşağzlanmayla karşı karşya kalabiliyorsunuz: Bu yüzden maksimum performans alabileceğim bir karakter olarak kendimi tanmmlamaya çalssyorum. Çok fą̧la sorumluluk sabibi olacak karakterlerin bana göre olduğunu dïsï̈nmüyorum" (SK-1).

Beş katılımcı oyunlardaki sanal dünyayı önemsediklerini belirterek avatar seçiminde grup aidiyetine dikkat ettiklerini söylemektedir. Sorumluluk, takım arkadaşlarına destek gibi unsurlara önem verdiklerini ifade eden katılımcılar avatarlarını da bu doğrultuda oluşturduklarına dile getirmektedir.

"Lider bir karakter olarak tanmlanmak hoșuma gidiyor. Oyun içinde arkadaşlarma direktif veren ve oyunu sürekli hisseden bir karakter olarak. kendimi tanmlyyorum. Bu sayede oyundan daba fazla zevk aldiğmı dïşünüyorum. (SE-3).

"Avatar seçiminde aksiyonu ön planda tutarm. Kendimi her zaman aksiyon içinde olan, doğru hamleler yapmaya çalsşan bir avatar olarak tanmlarm. Güclü olmak ve doğru zamanda doğru yerde duran bir avatar olmak benim için önemlidir" (ME-2).

Dört katılımcı avatar seçiminde liderlik unsuruna önem verdiklerini ifade etmektedir. Oyun içinde liderliğin kendilerini daha iyi hissettirdiğini belirten katılımcılar bu sayede oyuna olan bağllıklarının da arttı̆̆ına dikkat çekmektedir. Gofffman'ın performans kavramından hareketle bireylerin avatarlar aracılı̆̆yla bulundukları ortamı önemsedikleri ve buna uygun bir davranış biçimi sergiledikleri görülmektedir. Nitekim gruba ait olma isteği ve grupta liderlik rolü üstlenme davranışları bu savı desteklemektedir.

"Oyunda sectig̈im avatarla kendim arasinda herhangi bir bă̆ kurmuyorum. Cünkü zaten kadm karakter olușturduğum için kendimi çok da faz̧la avatara ait hissetmiyorum. Bu yüzden gerçekçi bir tammlama yaptrğğm söyleyemem" (ME-1).

Bir katılımcı avatarlar ile arasında bağ kuramadığını belirterek avatarların kendisine herhangi bir katkı sunmadığını dile getirmektedir.

\section{Avatar Seçimi ve Cinsiyet İlişkisi}

"Kadnn karakterleri seçmeye daha eğ̈limli olduğumu düs̈̈̈nӥyorum" (SK-1).

"Dijital oyunlarda avatar sę̧iminde ben her zaman kadn karakter segerim. Nedeni ise saatlerce iə̨lediğim bir seyin görsel açıdan estetik sunmasın isterim. Saatlerce ekran başında durduğum için bemcinsimden ziyade karşıt cinsimi seyretmek ve onunla basaryy ulasmak bana daha hos geliyor (ME-1).

"Avatar sę̧iminde karakterlerin bikâyelerini önemsiyorum. Baz̧ oyunlarda avatarlarn geçmişe dair bikâyeleri oluyor ve bu benim karakterle bir bağ oluşturmama vesile oluyor. Diğer yandan estetik. açıdan bakildăgrnda ben de kadn karakterleri daha fazla tercih ediyorum çünkü görsel estetiğ̈ önemsiyorum. Ayrica oyunlarda kadn karakterler genellikle daha hrz̨l oluyor ki bu da benim için önemlidir" (ME-3).

"Oyunlardaki avatarlarn bana benzemesi hoșuma gidiyor. Bu bana sanki ben de oyunun içindeymişim hissi veriyor. Bu yüzden günlük hayatıma uygun olan avatarlar secmeye dikkat ediyorum. Bunlar daba çok boşuma gidiyor" (ME-4).

"Eğer cinsiyetin oyuna bir etkisi yoksa genellikle kadn karakterleri seçiyorum. Cü̈nkü görsel estetiği ben de önemsiyorum. Oyunda etki varsa fižlksel açıdan güçlï olan ve beni basarrya götürecek olan avatarları seçmeyi tercih ediyorum" (ME-5).

On bir katılımcı avatar seçiminde karşı cins deneyimine önem verdiğini dile getirmektedir. Bu durum iki üst maddedeki benzetme ve hayal etme arzusu ile uyuşsa da özellikle erkek katılımcıların kadın avatarlara daha fazla yönelim göstermesi katılımcıların farklı bir kimliği deneyimleme arzusunun yanında görsel unsurlar ve estetiğe de önem verdiklerini ortaya koymaktadır. Bir katılımcı ise kadın ya da erkek fark etmeksizin oyunun gidişatına uygun bir avatar seçimi yaptı̆̆ını söylemektedir. 


\section{Eğlence Motivasyonu}

"Avatar seģiminde kendimi başarlh bir karakter olarak tanmlamayı seviyorum. Çünkü oyunlar bana göre bir gerçeklikten ziyade sanal bir dünyada vakit geçirmeyi sağlayan şeyler. Bu yü̈den eğlenceyi ön planda tutarm ama ayn zamanda basariyz da önemserim" (ME-6).

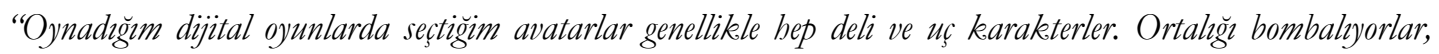
kostümleri replikleri çok delice ve eğlenceli. Bu özelliklerin hepsinin de gerçek, bayatuma uygun olduğunu düsünüyorum. Bu nedenle seçtiğgm avatarlarm kimlik yapım doğrudan yansittrğgn söyleyebilirim” (SK-1).

"Gerçek hayatta eğlenceli biriyimdir. Ama oyunlar biraz, ciddiye alyyorum. Mesela giyim konusunda örnek verecek olursam oyun içinde çok süslü şeyleri tercih etmem, ciddi kiyafetlere yönelirim. Cünkü oyunlar her ne kadar bir eğlence aracu olsa da içinde ciddiyet ve disiplin de barndiryor. Ben de gerçek. bayatta farkl düsü̈nsem de oyunda bu meseleye biraz önem veriyorum" (ME-2).

Görüşmecilerin ifadeleri eğlence amacıyla bu ortamlarda bulunduklanı dolayısıyla bir ihtiyaçlarını karşılayıp hedonik bir doyum elde ettiklerini göstermektedir. Katılımcılar aynı zamanda bu eğlence motivasyonunun kendilerini oyuna daha fazla bağladığını belirtmektedir. Zira oyun içinde yer alan ve günlük hayatta gerçekleşemeyecek birçok "fantastik" şeyi oyunlar aracilığıyla yapabildiklerini dile getiren katılımcılar bu durumdan hoşnut olduklarını ifade etmektedir.

\section{Çoklu Kimlikler: Gerçek/Sanal Kimlikler}

"Oyunlardaki avatarlarn kimlï̈imi yansittuğmn düsünüyorum. Cünkü oyun dizaynnda genellikle kendimi yansitan şeyleri tercih etmeyi seviyorum. Oyunlar eğlencesine oynasak da özellikle bikâyesi olan oyunlarda kendimi yansitmayz seviyorum. Bu sayede o dünyada var olabildig̈imi düş̈̈nӥyorum” (ME-4).

"Oyun içinde avatarlarn özelliklerini önemsiyorum. Ama ayn zamanda bu avatarlarn beni yansitmast gerektiğini de düsünüyorum. Cünkï oyun içinde kendimi oyuna ait bissetmem için avatarlarm benim kimlike yapima uygun olmast gerektiginini düsï̈nïyorum" (ME-5).

Katılımcılardan yedisi dijital oyunlarda avatar seçimi sırasında gerçek kimliklerine yakın özellikleri seçtiklerini belirtmektedir. Avatarların oyun içinde var olan her türlü statü ve durumunu kendileriyle bağdaştıran katıllımcılar karakterlerin kendilerine benzemesini vazgeçilmez bir koşul olarak görmektedir. Avatarlar ancak kendilerine benzedikleri takdirde sanal dünyada var olabildiklerini düşünen katılımcilar bu sayede oyunlara anlam yükleyebildiklerini söylemektedir.

"Gerçek hayattaki kimliğimle bağglantıll bir avatar seçtï̈imi düsünmüyorum. Çünkü oyunlarn gerçek, hayattan farkh olmast gerektig̈ini düsünüyorum. Oyunlar gerçek, bayatla aym şekilde oynasak o zaman eğlence bunun neresinde kalyyor ki? (ME-6).

"Benim oyundaki avatarmla gerçek hayatımdaki kimliğim arasinda bir bağlantı olduğunu düşünmüyorum. Bana göre oyunlar normalde yapamayacağım șeyleri yapmamı sağlayan, tamamen farkel bir kişi olmama firsat verebilen platformlardir. Bu nedenle oyunlarda gerçek yaşamdaki kimlï̆imi çok yansitmam. Çünkü oyunlar farkh bir düny a olarak görmek istiyorum ve farkh deneyimleri tecrübe ettigimde ne tür sonuclar alacağım görmek istiyorum" (ME-3).

Dört katıllımcı avatar seçiminde sanal kimliklere başvurduklarını söylemektedir. Gerçek hayattaki kimlik yapıları ile avatarlar arasında bağlantı kuramadıklarını belirten katılımcılar oyunları sanal bir dünya olarak adlandırarak onların gerçek hayattan farklı olması gerektiğini ifade etmektedir. Bu durumun temel sebebi oyun-gerçek arasındaki ayırımın yapılması ve oyunların tamamen bir sanallık içerisinde yer almasidir.

"Avatar seçimlerini önemsemediğim için oyunun bana verdiği imkânlar doğrultusunda hareket ediyorum.

Elimden geldig̈ince arkadaşlarma yardim ediyorum. Rakiplerimi zorlayarak onlar geride birakmaya çalssyorum ve bu durumun gerçek hayattaki kimlik yapımla da uyustugüunu düşünüyorum” (SE-2).

Bir katılımcı ise avatar seçimlerini önemsemediğini belirterek oyunun sunduğu imkânlarla sınırlı bir deneyim gerçekleştirdiğini ifade etmektedir. Oyunu yalnızca vakit geçirme ve eğlence kavramları üzerinden aktaran katılımcı ekstra bir beklenti içinde olmadığını dile getirmektedir. 


\section{Gerçek Yaşam ve Gerçeklik Algısı}

"Mesela GTA oyununda hiçbir görevi yerine getirmezdim. Sadece polis araçlarm tarayarak bile açyordum ve belikopterle çatilara çıearak suc seviyemi arttrmaya çalssyordum. Oyundaki tek amacım buydu. Sanirm gerçek hayatta gerçeklestiremeyeceğim eylemleri dijital oyunlar aracliğgyla gerçeklesstirmeye çališlyorum” (SK-1).

"Oyunlarda kural dişına ģımayn seviyorum. Ben de kendi âlemimde takilarak ve bile yaparak gerçek hayatın sunamayacağ şseyleri deneyimlemeye çalışzyorum” (SK-2).

Katılımcılardan altısı dijital oyunlarda gerçek dışı sunulan yaşamın kendilerine daha cazip geldiğini belirtmektedir. Bu durumu gerçek yaşamdan kaçış olarak adlandıran katılımcılar, kural dışı eylemleri gerçekleştirebilme özgürlügünü cazip bulduklarını dile getirmektedir. Oyunlardaki avatar seçimlerinde de gerçek yaşamdan bir kopuş sürecine ulaştıklarını belirten katılımcılar, Baudrillard'ın üzerinde durduğu simülasyon evreni dünyasına geçiş yapmaktadır.

"Oyun ortamında özgürlüğ̈̈mü yansitmak, hosuma gidiyor. Oyunlar bence insanlara özgürlük sunmaktadrr. Bu özgürlïğ̈ de baz̨en oyunlarda olağandlşı şeyleri yaparak sağlyorum. Zira bunlarn birçoğunu gerçek hayatta yapmak her zaman mümkïn olmuyor" (ME-3).

"Normalde gondola bindigimde baynlacak gibi oluyorum. Ama aksiyon oyunlarnda bu tür eylemleri gerçeklesstirmek hoșuma gidiyor. Mesela çatilardan atlyorum, paraşüt kullanyyorum. Sanirm gerçek hayatta yapamadĭgm seyleri oyunlarda yapmak beni tatmin ediyor" (SE-2).

Dört katılımcı oyunlarda özgür davranışlar sergilemenin önemine vurgu yapmaktadır. Oyunları özgürlüğün sunulabildiği platformlar olarak adlandıran katılımcılar olağan dışı olayların kendilerine heyecan ve oynama isteği sunduğunu dile getirmektedir.

"Oyunlarda kendimi yansitan avatarlar seçtiğim için oyun içinde de beni yansitan davranışlar sergilemeye

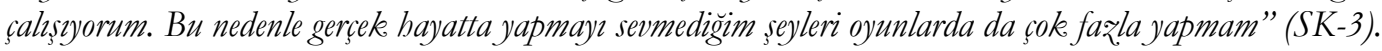

"Ben oyunlarda her ne olursa olsun gerçekçi bir davranış tercih ederim. Cü̈kü oyunlarda gerçek dişı davramşlar sergilendiğinde bu bana siber zorbahk gibi geliyor. Gerçek hayatta zorbah̆̆g hic sevmediğim için oyunlarda da bu doğrultuda bareket etmeyi tercib ederim" (ME-1).

İki katılımcı ise oyunlarda gerçek hayata uygun davranışlar sergilemenin elzem olduğuna dikkat çekmektedir. Aksi davranışların siber zorbalı̆̆a kadar uzanacak büyük bir sorunlar silsilesi oluşturabileceğine dikkat çeken katılımcılar oyunların sanal ortamlar da olsa birtakım kurallar dâhilinde oynanması gerektiğini söylemektedir. Gerçek hayatta yapmayacakları şeyleri oyunlarda da yapmayacaklarını belirten katılımcılar aksi halde kişilik yapılarına ters davranışlarla karşı karşıya kalacaklarını ifade etmektedir.

\section{Tartı̧̧ma, Sonuç ve Öneriler}

Bu çalışma, "Dijital oyunlarda belirlenen avatarlar kişilerin gerçek yaşamdaki kimlikleri ile nasıl bir ilişkiye sahiptir?” sorusu üzerine odaklanmıştır. Katılımcıların verdikleri yanıtlar üzerinden avatar-kimlik yapısı ilişkisine bakıldığında 6 ana başlı̆̆a ulaşılmıştır. Bunlar; "Avatar Seçiminde Benzetme ve Hayal Etme Arzusu", "Anonimlik, Grup Aidiyeti ve Liderlik", "Avatar Seçimi ve Cinsiyet İlişkisi", "Eğlence Motivasyonu”, "Çoklu Kimlikler: Gerçek/Sanal Kimlikler" ve "Gerçek Yaşam ve Gerçeklik Algısı'dır".

Elde edilen bulgular neticesinde benzetme ve hayal etme arzusu; Erving Goffman'in Günlük Yaşamda Benliğin Sunumu adlı eserinde üzerinde durduğu kişilerin toplumda kabul gören yapılara ilişkin davranışlar sergilemesi ve taklit, benzetme gibi kavramların kimlik oluşumundaki etkisine vurgu yapmaktadır. Katılımcıların özellikle hayal ettikleri kimlik yapılarına ulaşma arzusu aslında toplum nezdinde kabul görme ve başarılı insanları taklit etme doğasına dayanmaktadır. Bu açıdan bakıldığında benlik kavramı ön plana çıkmaktadır. Kenç ve Oktay'ın (2002, s. 72) "benlik, bireyin doğduğu andan itibaren geçirdiği yaşantıların sonucunda edinilen ve bu yaşantılarla gelişen bir yapıdır" ifadesi dijital oyunları oynayanların seçtikleri avatar üzerinden yeni bir benlik oluşturma çabası içerisine girdiklerini göstermektedir. Bu durum kendisini benzetme ve hayal kurma üzerinden sergilenmektedir.

Çalışmada elde edilen bir diğer bulgu olan “anonimlik, grup aidiyeti ve liderlik” Bilgin'in (2014) benlik tanımı sırasında yer verdiği grup aidiyeti ve sosyal statü ile gelen rol kavramlarına vurgu yapmaktadır. Katılımcılar seçtikleri avatarlarda grup aidiyetine önem vermektedir. Çünkü grup içerisinde yer almak onları hem yeni bir sanal dünyaya geçirmektedir hem de bu dünyada oluşturdukları sanal kimlikler ile grup içerisinde var olabilme isteklerini yerine getirmektedir. Trpkı aidiyette olduğu gibi 
liderlikte de temel amaç avatarlar üzerinden yeni bir sosyal kimlik yapısı inşa etme çabasına girmektir. Anonimlik ise Spears ve Lea'nın dijital ortamlardaki anonimlik ve kimlik belirsizliği üzerinden oluşan yeni dijital kimlik yapılarına yaptığı vurguyla uyum sağlamaktadır. Bireylerin bu yeni yapı içinde gün geçtikçe gerçek kimliklerinden soyutlanmaları mekânsal ve zamansal anlamda yeni bir boyutta özgürleşerek istedikleri kimliği oluşturabildiklerine dikkat çekmektedir. Nitekim görüşmelerden elde edilen veriler de bunu doğrulamaktadır. Bireylerin oyun ortamında istedikleri özelliklerle yeni kişiler yarattıkları aşikârdır. Bu belirsizlik ve anonimlik aynı zamanda sorumluluktan da kurtulmak olarak görülmektedir. Bir görüşmecinin fazla sorumluk sahibi olacak karakterleri tercih etmediğini söylemesi katılımcıların neden farklı karakter özelliklerini tercih ettiklerinin ifadesi olarak görülebilir.

“Avatar seçimi ve cinsiyet ilişkisi” kavramı Binark ve Bayraktutan-Sütcü (2008) ile Bertle'nin (2001) üzerinde durduğu persona tanımıla uyuşmaktadır. Persona evreni ile birlikte oyuncu-gerçek ayrımı sona ermektedir ve oyuncu bizatihi karakterin kendisine dönüşmektedir. Katılımcıların yorumlarında kadın karakterleri sahiplenmeleri, özelliklerini yüceltmeleri ve görsel unsurlar üzerinden bu karakterleri tercih etmeleri sanal uzamda yaratılan bu karakterlerin zamanla gerçeklik algısına dönüştüğüne işaret etmektedir. Yine sanal dünyada yaratılan kimliklerin bu denli güçlü olmasında dijital habitusların önemi büyüktür. Bireyler bu habituslar aracıllğılyla kendilerine yeni bir dünya oluşturmaktadır ve bu dünyada kendilerini istedikleri şekilde konumlandırabilmektedir.

"Çoklu Kimlikler: Gerçek/Sanal Kimlikler" kavramı katılımcıların avatarlar aracıllğıyla elde ettikleri kimlik yapılarını zamanla sanaldan gerçeğe evrilen bir kimlik yapısına dönüştürdüklerini ortaya koymaktadır. Burada ilk olaran Baudrillard'ın simülasyon evreni tanımı ön plana çıkmaktadır. Bireylerin sanal olan yapıyı zamanla gerçeğe dönüştürmesi ve hipergerçekliğe ulaşması gerçekten sanala olan geçişi doğru bir şekilde ifade etmektedir. Yine Turkle'nin (1997) sanal kimliklerin zamanla kişilerin gerçek ilişskilerini etkilediklerine yönelik savı da kattlımcıların yorumları ile örtüşmektedir. Boyd'un ise bireylerin kimliklerini bulundukları ortama göre inşa ettiklerine yönelik ifadesinde olduğu gibi oyunun verdiği imkânlara göre hareket etmek isteyen katılımcılar ortamda kendini kabul ettirebilmek için bu sanal evrene daha hızlı bir geçiş yaşamaktadır. Nitekim katılımcıların gerçek hayattaki kimlik yapılarını avatarlara yansitmak istemeleri bunun bir sonucu olarak yorumlanabilmektedir. Diğer yandan 2 katılımc ise avatarlar ile gerçek yaşamdaki kimlikleri arasında bir bağlantı kurmadıklarını belirtmektedir. Bu durumun temel sebebi oyun-gerçek arasındaki ayrımın yapılması ve oyunların tamamen bir sanallık içerisinde yer aldığının düşünülmesidir. "Gerçek Yaşam ve Gerçeklik Alg1sı" kavramı da aslında bir üst madde ile benzerlik sunmaktadır. Zira katılımcılar avatarlar aracıllğıyla gerçek yaşamdan kopuş sürecine ulaştıklarını belirterek Baudrillard'ın simule evrenine geçiş sağlamaktadır.

Elde edilen tüm bulgulara bakıldığında katılımcıların seçtikleri avatarların kimlik ve benlik yapıları üzerinde birçok etki oluşturduğu görülmektedir. Bu etkilerden ilki bireylerin sanal dünya içerisinde kendilerini daha özgür ve güçlü bir şekilde tanımlamalarıdır. Oyun dünyasında birtakım müeyyidelerin olmaması ve yaptırımların gerçek hayatla bağdaşmayacak şekilde az olması katılımciların bu sanallı̆ga olan bağlılıklarını arttırmaktadır. Dikkat çeken bir diğer etki ise sanal dünya içerisinde var olma isteği ve bu dünyayı realite haline dönüştürme çabalarıdır. Katılımcılar oyun oynama sırasında bir yandan geçirdikleri zamandan zevk alırken diğer yandan bu dünyayı ciddiye almaktadırlar. Çünkü bu dünya içerisinde gruplara ayrılmaları, kendilerine ait klanlar oluşturmalan ve birtakım liderler atamaları aslında onların bu dünyaya görünenden daha fazla önem verdikleri sonucunu doğurmaktadır.

Katılımcılar avatarların kimlik ve benlik yapıları üzerinde oluşturduğu etkilerden söz ederken çoklu ve sanal kimlik kavramlarının üzerinde durmuştur. Gerçek dünyada deneyimlenemeyecek bir kimlik yapısına sahip olmak katılımcıları heyecanlandırmaktadır. Bunun neticesinde bir yandan sanal dünyada çoklu kimlikler oluşurken diğer yandan Bourdieu'nun üzerinde durduğu habitus kavramı bağlamında bu yapıyı hayatlarının temeline yerleştirmektedirler.

Dijital oyunlar aracılığıyla oluşturulan avatarlar kişilerin kimlik yapılarına da etkide bulunmaktadır. Bu etkiler zaman zaman kişilerin gerçek dünya ile sanal dünya arasındaki ayrımı anlayamamalarına neden olmaktadır. Gerçek ile sanalın ayırımının yapılamadığı bir dünyada avatarlar üzerinden oluşturulan deneyimler kişilerin yaşamlarında birtakım sorunlar oluşturabilme potansiyeline sahiptir. Dijital oyunlar aracılı̆̆ıyla oluşturulan avatarlar kişilere birtakım deneyimler sunmaktadır. Buna karşın oluşabilecek olumsuzluklara karşı da önlemler alınmalıdır. Öncelikli olarak 18 yaş altı bireylerin oyun platformlarını kullanımlarında ebeveyn denetimleri sıklaştırılmalı ve oyun üreticilerinin şiddet, cinsellik ve suça meyil oluşturabilecek yapılardan kaçınmaları gerekmektedir. Bir diğer önemli husus ise teknoloji ve dijital oyun 
okuryazarlığıdır. Bireylerin oyunlar aracılığıyla oluşacak her türlü olumsuzluğa karş1 medya metinleri, bilgilendirme notları ve eğitimler ile bilinçlendirilmesi elzemdir.

\section{Etik Beyan}

"Dijital Oyunlarda Avatar-Kimlik İlişkisi: Üniversite Öğrencileri Üzerine Bir Araștrma" başlıklı çalışmanın yazım sürecinde bilimsel kurallara, etik ve alıntı kurallarına uyulmuş; toplanan veriler üzerinde herhangi bir tahrifat yapılmamış ve bu çalışma herhangi başka bir akademik yayın ortamına değerlendirme için gönderilmemiştir. Gerekli olan etik kurul izinleri Yalova Üniversitesi İnsan Araştırmaları Kurulu'nun 11.03.2021 tarih ve 2021/24 sayıli toplantısında alınmışır.

\section{Kaynakça}

And, M. (2019). Oyun ve bügü türk, kültüründe oyun kavramı (5. Bask1). İstanbul: Yap1 Kredi Yayınlar1.

Aydın, B. (1996). Benlik kavramı ve ben şemaları. M.Ü. Atatürk Eg̈tim Fakïltesi Eğitim Bilimleri Dergisi, 8, 41-47.

Bakıroğlu, C. T. (2014). Sosyalleşme ve kimlik inşası ekseninde sosyal paylaşım ağları. Akademik bilişim (ss. 10471055). Antalya, Türkiye.

Bargh, J. A. ve Mckenna, K. Y. A. (2004). The internet and social life. Annual Review of Psychology, 55(1), 573-590.

Barmanbek, B., Fidaner, I. B. ve Merlin'in Kazanı (2009). Dijital oyun kültürü sözlüğü. İçinde M. Binark., G. Bayraktutan-Sütcü ve I. B. Fidaner (Haz.), Dijital oyun rebberi oyun tasarmm türler ve oyuncu (ss. 349-366). İstanbul: Kalkedon Yayınları.

Bartle, R. A. (2001). Avatar, character, persona. https://mud.co.uk/richard/acp.htm 23.12.2020.

Bartle, R. A. (1999). Multi-user dungeons. https://mud.co.uk/richard/ifan294.htm 25.12.2020.

Batı, U. (2011). Sekizinci sanatın inşası: "Dijital oyunlar kesişiminde postmodernizm, tüketim kültürü, üst gerçeklik, kimlik ve olağan şiddet". İçinde G. T. Ünal ve U. Batı (Edt), Dijital oyunlar: "Kendi dünyanda yaşa biziminkinde oyna". (ss. 3-34). İstanbul: Derin Yayınları.

Baym, N. K. (1998). The emergence of on-line community. In S. G. Jones (Eds), Cybersociety 2.0 revisiting computermediated communication and community (pp. 35-68). New York: Sage Publications.

Bayraktutan-Sütcü, G. (2009). Ciddi oyunlar. İçinde M. Binark., G. Bayraktutan-Sütcü ve I. B. Fidaner (Haz.), Dijital oyun rebberi oyun tasarmo türler ve oyuncu (ss. 313-322). İstanbul: Kalkedon Yayınlar1.

Berne, E. (2011). Games people play the psychology of buman relationships kindle edition. New York: Tantor.

Bilgin, N. (2014). Kimlike inşası. İzmir: İzmir Büyükşehir Belediyesi ve Nuri Bilgin.

Bilgi Teknolojileri Kurumu. (2018). 1 milyarın üzerinde insan dijital oyun oynuyor, https://www.btk.gov.tr/haberler/1 milyarin-uzerinde-insan-dijital-oyun-oynuyor, 25.04.2020.

Binark, M. ve Bayraktutan-Sütcü, G. (2009). Devasa çevrimiçi oyunlarda türklüğün oynanmass: Silkroad Online'da sanal cemaat inşası ve türk klan kimliği. İçinde M. Binark., G. Bayraktutan-Sütcü ve I. B. Fidaner (Haz.), Dijital oyun rebberi oyun tasarmm türler ve oyuncu (ss. 275-312). İstanbul: Kalkedon Yayınlar1.

Binark, M. ve Bayraktutan-Sütcü, G. (2011). Dijital oyun kültürü haritasında oyuncular: Dijital oyuncuların habitusları ve kariyer türevleri. İçinde A. T. Aydemir (Haz), Kathlimm "e-hali" genclerin sanal alemi (ss. 303-330). İstanbul: Alternatif Bilişim Derneği.

Binark, M. ve Bayraktutan-Sütcü, G. (2008). Kültür endüstrisi ürünü olarak dijital oyun. İstanbul: Kalkedon Yayınları.

Binark, M. (2009). Türkiye'de yeni bir yaratıcı endüstri: oyun stüdyoları ve dijital oyunlarda değer zincirinin üretilmesi.İçinde M. Binark., G. Bayraktutan-Sütcü ve I. B. Fidaner (Haz.), Dijital oyun rebberi oyun tasarmm türler ve oyuncu (ss. 125-170).

Bourdieu, P. (1995). Pratik nedenler (Çev: H. Tufan). Ankara: Kesit Yayıncıllk.

Boyd, D. (2007). "Why youth (heart) social network sites: The role of networked publics in teenage social life". In D. Buckingham (Eds), MacArtbur foundation series on digital learning - youth, vdentity, and digital media volume (pp. 119142). Cambridge: MA: MIT Press.

Bozkurt, A. (2014). Homo ludens: Dijital oyunlar ve eğitim. Eğitim Teknolojileri Arasttrma Dergisi, 5(1), 1-20.

Cizmeci, E. (2014). Danah Boyd'da sosyal ağlar ve gençlik. İçinde M. Çakır (Edt), Yeni medyaya eleşstirel yaklaşımlar (ss. 383-410). İstanbul: Doğu Kitabevi.

Clark, J. S. (2011). Second chances: Depictions of the natural world in second life. In A. Ensslin ve E. Muse (Eds), Creating second lives community, identity and spatiality as constructions of the virtual (pp. 145-168). New York: Routledge.

Curtis, P. ve Nichols, D. A. (1994). MUDs grow up: social virtual reality in the real world. Proceedings of COMPCON '94 (pp. 193-200). San Francisco, Amerika Birleşik Devletleri.

Çiçekli, A. (1970). Kassgarl Mahmud divan ü lügat-it türk. İstanbul: May Yayınları.

Doğu, B. (2009). Yeni bir türün inşası: Gerçek yaşam simülasyonları. İçinde M. Binark., G. Bayraktutan-Sütcü ve I. B. Fidaner (Haz.), Dijital oyun rebberi oyun tasarmm türler ve oyuncu (ss. 247-274). İstanbul: Kalkedon Yayınlar1.

Dong, L. D., Liau, A. ve Khoo, A. (2013). Player-avatar identification in video gaming: Concept and measurement. Computers in Human Behavior, 29(1), 257-263.

Ellison, N. B. ve D. Boyd. (2013). M.:Sociality through social network sites. In W. H. Dutton (Eds), The oxford bandbook of internet studies (pp. 151-172). Oxford: Oxford University Press. 
Etil, H. ve Demir, M. (2014). Pierre Bourdieu'nün bilim sosyolojisine katkisi: "Alan teorisi", "habitus" cini ve "refleksivite talebi". Cogito Dergisi Pierre Bourdieu Sayısı, 76, 312-349.

Fidaner, I. B. (2009). Sözcüklerden yapılmış dünyalar: MUD’lar. İçinde M. Binark., G. Bayraktutan-Sütcü ve I. B. Fidaner (Haz.), Dijital oyun rehberi oyun tasarmm türler ve oyuncu (ss. 233-246). İstanbul: Yayınlar1.

Frasca, G. (2003). Simulation versus narrative: Introduction to ludology. In M. J. P. Wolf ve B. Perron (Eds), Video/game/theory (pp. 221-235). New York: Routledge.

Giddens, A. (2010). Modernite ve bireysel-kimlik: Geç modern çă̆da benlik ve toplum (Çev: Ü. Tatlican). Ankara: Say Yayınları.

Goffman, E. (2012). Günlük yaşamda benliğin sunumu (Çev: B. Cezar). İstanbul: Metis Yayınları.

Golz, P. ve Mitra, B. (2016). Exploring intrinsic gender identity using second life. Journal of Virtual Worlds Research, 9(2), 1-17.

Gülsoy, S. (2017). Dijital oyuncu kimliğinin inșası ve sunumu (Doktora Tezi). Atatürk Üniversitesi Sosyal Bilimler Enstitüsü, Erzurum.

Gündüz, F. (2014). Sosyal medya'da çftkimliklilik (Yüksek Lisans Tezi). Marmara Üniversitesi Sosyal Bilimler Enstitüsü, İstanbul.

Güvenli İnternet Merkezi. (2019). Dijital oyunlar raporu 2019. https://www.guvenliweb.org.tr/dosya/RjARy.pdf 13.03.2020.

Güzel, E. (2016). Dijital kültür ve çevrimiçi sosyal ağlarda rekabetin aktörü: "Dijital habitus". Gümüşhane Üniversitesi İletisim Fakültesi Elektronik Dergisi, 4(1) 82-103.

Hogg, M. A. ve Vaughan, G. M. (2011). Sosyal psikoloji (Çev: İ. Yıldız ve A. Gelmez). Ankara: Ütopya Yayınları.

Huizinga, J. (2015). Homo ludens oyunun toplumsal işlevi üzerine bir deneme (Çev: M. A. K1liçbay). İstanbul: Ayrıntı Yayınları.

Jenkins, R. (2014). Social identity. New York: Routledge.

Jones, D. E. (2006). I, avatar: constructions of self and place in second life and the technological imagination. http://www.gnovis.georgetown.edu/ 23.12.2020.

Kenç, M. F. ve Bünyamin, O. (2002). Akademik benlik kavramı ve akademik başarı arasındaki ilişki. Eğitim ve Bilim, 27(124), 71-79.

Kendirli, T. (2019). Dijital oyun terminolojisi (Çev: Ö. Özüpek). İstanbul: Abaküs Kitap Yayın Dağıtım Hizmetleri.

Kepenek, E. B. (2020). Yeni ve yükselen bir alan: Dijital oyunlar sosyolojisi. Sosyoloji Arastırmalar Dergisi, 23(2), 186213.

Kerr, A. (2006). The business and culture of digital games gamework/gameplay. London: Sage Publications.

Kukul, V. (2013). Oyunla ilgili tarihsel gelişim ve yaklaşımlar. İçinde M. A. Ocak (Edt), Ë̆ğtsel dijital oyunlar kuram, tasarm ve uygulama (ss.20-31). Ankara: Pegem Akademi.

Marsh, T. (2011). Serious games continuum: Between games for purpose and experiential environments for purpose. Entertainment Computing, 2(2), 61-68.

Micheael, D. ve Chen, S. (2006). Serious games: Games that educate, train and inform. Boston: Thomson Course Technology.

Newzoo. (2018). Global game market report Premium, https://newzoo.com/ 20.04.2020.

Nørgård, R. T. (2011). The joy of doing: The corporeal connection in player-avatar identity. Philosophy of Computer Games 2011 (pp. 1-15). Atina, Yunanistan.

Oskay, Ü. (2001). Mü̊ik ve yabancılaşma Aristo, Huizinga, ve Adorno açısıdan bir ön çalısma. İstanbul: Der Yayınları.

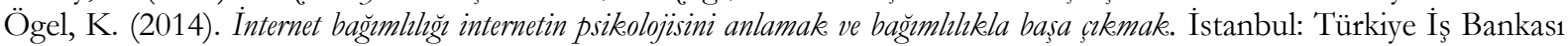
Kültür Yayınları.

Özdoğan, M. M. (2005). Oyun, ütopya ve spor. Toplum ve Bilim, 103, 44-52.

Özen, Y. ve Gülaçtı F. (2010). Benlik-kavramı ve benliğin gelişimi bilen benliğe gereksinim var mı?. Eræ̨incan Ë̈itimFakültesi Dergisi, 12(2), 20-38.

Sarıyar, H. (2019). Dijital çağda kimliğin kavramsallaştırlması ve gerçeklik: Twitter parodi hesaplar (Yüksek Lisans Tezi). Marmara Üniversitesi Sosyal Bilimler Enstitüsü, İstanbul.

Sezen, T. İ. (2011). Dijital oyunları anlamak: Oyun, anlat1, yazılım ve platform perspektiflerinden dijital oyunlar. İçinde G. T. Ünal ve U. Batı (Edt), Dijital oyunlar: "Kendi dünyanda yaşa biæimkinde oyna". ss. 119-148). İstanbul: Derin Yayınları.

Sezen, T. İ. ve Sezen, D. (2011). Dijital oyun tarihinin dönüm noktaları oyunlar, yorumlar, teknolojik ve toplumsal gelişmeler. İçinde G. T. Ünal ve U. Batı (Edt), Dïital oyunlar: "Kendi dünyanda yaşa biæimkinde oyna". (ss. 249- 284). İstanbul: Derin Yayınları.

Sorensen, B. H. ve Meyer, B. (2007). Serious games in language learning and teaching - a theoretical perspective. Proceedings of DiGRA 2007 Conference Digital Games (pp. 559-566). Tokyo, Japonya.

Soyseçkin, İ. (2007). Sanal uzamda ve mudlarda eril-dişil kimliklerinin yeniden inşası. İçinde M. Binark (Edt), Yeni medya çalşsmalar (ss. 251-280). Ankara: Dipnot Yayınları.

Spears, R. ve Martin, L. (1994). Panacea or panopticon? The hidden power in computer-mediated communication. Communication Research, 21, 426-459.

Stryker, S. ve Burke, P. J. (2000). The past, and future of an identity theory. Social Psychology, 63(4), 284-297. 
Suh, K. S., Kim, H. ve Suh, E. K. (2011). What if your avatar looks like you? Dual congruity perspectives for avataruse. MIS Quarterly, 35(3) 711-729.

Susi, T., Johannesson M. ve Backlund P. (2007). Serious Games- An Overview, Technical report. Skövde: University of Skövde.

Teng, C. (2017). Impact of avatar identification on online gamer loyalty: Perspectives of social identity and social capital theories. International Journal of Information Management, 36(6), 601-610.

Tetir, D., İ. Kılıç, S. ve M. Topcu. (2020). The sims oyununda para hileleri kullanan ve gündelik yaşantısında yoksulluk sorunu olan genç bireylerin öznel iyi oluşlarının değerlendirilmesi. İçinde M. Topcu (Edt), Oyun ve kültür üzerine psikolojike okumalar (ss. 1-26). Ankara: Akademisyen Kitabevi.

Tezel, Y. (2016). Bilgisayar oyunlar taribi. İstanbul: Sokak Kitaplar1.

Turkle, S. (1997). Life on the screen identity in the age of the internet. New York: Touchstone Book.

Turkle, S. (1996). Parallel lives: Working on identity in virtual space. In D. Grodin ve T. R. Lindlof (Eds), Constructing the self in a mediated world (pp. 156-178). London: SAGE Publications.

Turkle, S. (2005). The second self: computers and the buman spirit. Massachusetts: The MIT Press.

Tutar, H. (2014). Sosyal psikoloji kavramlar ve kuramlar. Ankara: 2014.

Türk Dil Kurumu. (2020). Oyun. https://sozluk.gov.tr/ 03.06.2020.

Türktaş, M. (1999). Divani Lügatit-Türk'te yer alan ve XI. yüzyılda Türkler arasında oynanan oyunlar. Pamuk,kale Üniversitesi Eğitim Fakültesi Dergisi, 6(5), 61-65.

Waggoner, Z. (2009). My avatar, my self identity in video role-playing games. North Carolina: McFarland \& Company Publishers.

Yengin, D. (2012). Dijital oyunlarda şiddet. İstanbul: Beta Yayınlar1.

Yıldırım, A. ve Simșek, H. (2016). Sosyal bilimlerde nitel arastırma yöntemleri (10. Baskı). Ankara: Seçkin Yayıncılık.

Yurdam, S. (2018). Alan olarak dijital oyun, çocuk eyleyiciler ve tahakküm: Clash of clans oyunu üzerine bir inceleme. Intermedia International e-Journal, 5(8), 66.

\section{EXTENDED ABSTRACT}

The game, which is based on a process older than the existence of life, has played an important role in shaping the societies themselves. With the existence of humanity, games, which have become an important tool for people to prepare for life and gain some experiences, have undergone many changes throughout history. Games, which have acquired a new form in every social event experienced, have begun to take the form of leisure entertainment with the effects of increasing secularization and capitalism after the Industrial Revolution. Games, which offer important alternatives for people to evaluate their spare time outside of work, have started to have a digital structure with the developing internet technologies since the 1960s. Games that evolved from real time and spaces to virtual spaces and times after the 1960s laid the groundwork for the discussion of the concept of digital games.

Changes in games in the digitalization process are not limited to this area. The identity and selfstructures of people have also started to enter the digitalization adventure with the internet and especially with the social media platforms that have emerged in the last 20 years. The simulation universe put forward by Baudrillard and the desire of people to exist in a new environment have led to an increase in virtual identity discussions. Digital games also had a significant impact on this emerging new identity construction process. The digital game industry, which has increased its income rapidly in recent years and left many other entertainment industries behind, has enabled individuals to both create virtual communities and exist in these virtual environments through virtual environments such as Steam and Play Station Store. In such a world, it has revealed the problem of what kind of effect the avatars created through digital games have on the identity structures of people.

In this study, the problem of how the avatars in digital games affect the identity structures of people in their real lives is emphasized. In this context, the main question of the study is "What kind of relationship do avatars in digital games have with identity structures in real life?" as; The aim of the study is to reveal the effect of this relationship on the identity and self-formation of the person. In the study, Yalova University Faculty of Art and Design Communication Arts department 3rd grade students (SK and SE) and Yalova University Engineering Faculty Computer Engineering department 4th grade students (ME) were selected. Communication Arts students represent social sciences, Computer Engineering students represent science. The students consist of a total of 12 students selected from the universe with the purposeful sampling/snowball sampling method. In the study, students; "What are the elements you pay attention to when choosing an avatar while playing a digital game? Which features do you think come to the fore?", "What kind of character do you try to define yourself as when choosing an avatar?", "To what extent do you think the avatars you choose in digital games reflect your identity in real life?" and "To 
what extent can you reflect behaviors that you do not/cannot exhibit in real life through avatars in digital games? questions were posed.

Changes in the self-concept since the 16th century pushed people to have a social identity structure with industrialization. In today's digitalization era, individuals have started to build a portable social identity structure through avatars. Secularization and positivist approaches in relation to the self-concept have caused people to prioritize worldly feelings more. In this context, together with the developing technology, first mass media, then the internet and digital games have taken their places as applications that serve this purpose.

When the identity and self-relationship was emphasized, another striking factor was that the participants cared about the personality and physical characteristics in the game in their avatar selection. Because it was concluded that the participants met some of their needs through these avatars and thus reached satisfaction. Again, anonymity and ambiguity are also created, giving the impression that the new virtual identity isolating people from the real world and pushing them into an artificial universe. As a matter of fact, the fact that one of the interviewees said that he did not prefer characters that would have more responsibility can be seen as an expression of why they prefer different character traits.

Based on Goofman's concept of performance, individuals engage in activities that have an impact on and in front of other players through their avatars. If we need to evaluate Goffman's concept of performance through digital games, it can be said that the performance created on the platforms and the created virtual identity reflect the persona of the individual. As in the real world, opinions about individuals are formed as a result of these performances, and as a result of these opinions, identity and personality determinations are formed. In other words, individuals try to create a new identity for themselves with their performances in the virtual environment or the performances they try to show. Since the performance is also a bridge that carries the individual to the persona, it is the point where the individual is completely isolated from himself and turns into a character, and now he feels like him and identifies with him. This is the peak of pleasure and satisfaction from games. Because the individual has now reached a new identity. In the findings obtained from the research, it was revealed that the interviewees reached this point.

As a result, it is seen that individuals make a great effort to create themselves in this new universe formed through digital games. Especially in this new world, it is thought that people create their avatars according to some rules and needs rather than random choices. It is thought that these needs and rules basically consist of two elements. The first is the identity structures that people want to experience and the second is their desire to show themselves more strongly in the virtual world by strengthening their existing identity structures. 